NBER WORKING PAPER SERIES

\title{
EDUCATION AND MORTALITY: \\ EVIDENCE FROM A SOCIAL EXPERIMENT
}

\author{
Costas Meghir \\ Mårten Palme \\ Emilia Simeonova \\ Working Paper 17932 \\ http://www.nber.org/papers/w17932 \\ NATIONAL BUREAU OF ECONOMIC RESEARCH \\ 1050 Massachusetts Avenue \\ Cambridge, MA 02138 \\ March 2012, Revised August 2017
}

Previously circulated as "Education, Health and Mortality: Evidence from a Social Experiment." We thank the editor Alexandre Mas, two anonymous referees, Douglas Almond, Anne Case, Meltem Daisal, Angus Deaton, Sergei Koulayev, Ilona Koupil, Amanda Kowalski, Ilyana Kuziemko, Per Pettersson Lidbom, Adriana Lleras-Muney, Bentley McLeod, Doug Miller, Sendhil Mullainathan, Torsten Persson, Diane Schanzenbach and Kosali Simon as well as from participants in seminars at Tufts University, Princeton University, the University of New Hampshire, Case Western Reserve University, SOFI, CHESS and IIES at Stockholm University as well as at the Nordic Summer Institute in Labor Economics at the Faroe Islands and the IHEA conference in Toronto for helpful comments on earlier drafts of the paper. Financial support from the IFAU is gratefully acknowledged. The views expressed herein are those of the authors and do not necessarily reflect the views of the National Bureau of Economic Research.

NBER working papers are circulated for discussion and comment purposes. They have not been peer-reviewed or been subject to the review by the NBER Board of Directors that accompanies official NBER publications.

(C) 2012 by Costas Meghir, Mårten Palme, and Emilia Simeonova. All rights reserved. Short sections of text, not to exceed two paragraphs, may be quoted without explicit permission provided that full credit, including $\odot$ notice, is given to the source. 
Education and Mortality: Evidence from a Social Experiment

Costas Meghir, Mårten Palme, and Emilia Simeonova

NBER Working Paper No. 17932

March 2012, Revised August 2017

JEL No. I12,I18,I21

\section{ABSTRACT}

We examine the effects of a major Swedish educational reform, that increased the years of compulsory schooling, on mortality and health. Using the gradual phase-in of the reform between 1949 and 1962 across municipalities, we estimate insignificant effects of the reform on mortality in the affected cohorts. From the confidence intervals we can rule out effects larger than 1-1.4 months of increased life expectancy. We find no significant impacts on mortality for individuals of low SES backgrounds, on deaths that are more likely to be affected by behavior, on hospitalizations, and consumption of prescribed drugs.

Costas Meghir

Department of Economics

Yale University

37 Hillhouse Avenue

New Haven, CT 06511

and IZA

and also NBER

c.meghir@yale.edu

Mårten Palme

Department of Economics

Stockholm University

SE-106 91 Stockholm

SWEDEN

and IZA

Marten.Palme@ne.su.se
Emilia Simeonova

JHU Carey School of Business

100 International Drive

Baltimore, MD 21202

and NBER

emilia.simeonova@gmail.com 


\title{
Education and Mortality: Evidence from a Social Experiment By Costas Meghir, Mårten Palme and Emilia Simeonova*
}

\begin{abstract}
We examine the effects of a major Swedish educational reform, that increased the years of compulsory schooling, on mortality and health. Using the gradual phase-in of the reform between 1949 and 1962 across municipalities, we estimate insignificant effects of the reform on mortality in the affected cohorts. From the confidence intervals we can rule out effects larger than 1-1.4 months of increased life expectancy. We find no significant impacts on mortality for individuals of low SES backgrounds, on deaths that are more likely to be affected by behavior, on hospitalizations, and consumption of prescribed drugs.
\end{abstract}

\footnotetext{
* Meghir: Department of Economics, Yale University Box 208264 New Haven, CT 06520-8264, USA; NBER, IFS and ESRC (e-mail: C.Meghir@yale.edu); Palme: Department of Economics, Stockholm University, SE-106 91 Stockholm, Sweden (e-mail: Marten.Palme@ne.su.se); Simeonova: Johns Hopkins University, 100 International Drive, Baltimore, MD, USA and NBER (e-mail: Emilia.Simeonova@gmail.com). We thank the editor Alexandre Mas, two anonymous referees, Douglas Almond, Anne Case, Meltem Daisal, Angus Deaton, Sergei Koulayev, Ilona Koupil, Amanda Kowalski, Ilyana Kuziemko, Per Pettersson Lidbom, Adriana Lleras-Muney, Bentley McLeod, Doug Miller, Sendhil Mullainathan, Torsten Persson, Diane Schanzenbach and Kosali Simon as well as from participants in seminars at Tufts University, Princeton University, the University of New Hampshire, Case Western Reserve University, SOFI, CHESS and IIES at Stockholm University as well as at the Nordic Summer Institute in Labor Economics at the Faroe Islands and the IHEA conference in Toronto for helpful comments on earlier drafts of the paper. Financial support from the IFAU is gratefully acknowledged.
}

The strong correlation between socio-economic status (SES) and health is one of the most recognized and studied in the social sciences. Economists have pointed at differences in resources, preferences and knowledge associated with different SES groups as possible explanations (see e.g. Grossman, 2006, for an overview). However, a causal link between any of these factors and later life health is hard to demonstrate and the relative importance of different contributing factors is far from clear. A series of studies (e.g. Lleras-Muney, 2005; Oreopoulos, 2006; Clark and Royer, 2013, Lager and Torssander, 2012; summaries in Mazumder, 2008 and 2012), use regional differences in compulsory schooling laws or changes in national legislations on compulsory schooling as a source of exogenous variation in educational attainment in order to identify a causal effect of education on health. The results from these studies are mixed. Lleras-Muney (2005) for the US, Oreopoulos (2006) for the UK and van Kippersluis, O'Donnell, and van Doorslaer (2011) for the Netherlands find a strong link between attained schooling and adult health and mortality, Lager and Torssander 
(2012) find some effects, while Clark and Royer (2013) cannot reject the null hypothesis that extra schooling has no impact on later-life health. Analyzing outcomes of twins Behrman et al. (2011) find no causal impact of schooling on health in Denmark.

In this paper we study the long-term health consequences of the introduction of a comprehensive school in Sweden, which mandated an increase in the number of years of compulsory schooling from 7 or 8 years (depending on municipality) to a new compulsory national level of 9 years. The reform was intentionally phased in between 1949 and 1962 by being adopted early by some municipalities while others delayed its introduction. The reform had a sizeable impact on educational attainment in Sweden (Meghir and Palme, 2005; Holmlund, 2007; Spasojevic, 2010; Meghir et al., 2012). Prior work has shown that labor earnings increased later in life for those exposed to the comprehensive school, in particular for children born in homes with low educated fathers (Meghir and Palme, 2005).

We use register data including about 1.5 million individuals born between 1940 and 1957 , which enables us to link assignment of type of school system to individual information from national registers on three different health outcomes. First, we study mortality using date and cause of death from the national Swedish Cause of Death Register. ${ }^{1}$ The follow-up period stops in December 31, 2015, which means that the birth cohort born in 1940 is aged 75 when we stop observing them. Second, we look at hospitalization by cause using the Swedish Inpatient register containing all hospitalization dates and ICD diagnosis codes for all hospital stays in Sweden between 1987 and 2014. Finally, we use the national Prescription register containing information on quantities and Anatomical Therapeutic Chemical (ATC) codes for all prescribed drugs in Sweden between 2005 and 2015.

We consider the impact of the reform on overall mortality as well as on death by cause. We first distinguish between deaths caused by circulatory diseases, shown here to be strongly associated with educational attainment, and by cancer, which is the main cause of death in the age group we study. We also consider causes of death classified by epidemiologists as "treatable" and "preventable" causes.

We use two estimation strategies. First, a difference-in-differences (DiD) approach that compares changes in mortality outcomes across cohorts in municipalities that implemented the reform compared to those that did not. Since we use 14 years of gradual implementation across the (approximately) 1,000 municipalities, we have many such comparisons, leading to

${ }^{1}$ See Socialstyrelsen (2009a). 
very high levels of precision. The second approach, a regression discontinuity (RD), exploits the cutoff date for assigning a child to a school year. In the calendar year when the reform is implemented the children born before $1^{\text {st }}$ January are assigned to the pre-reform system, while those born after that date are assigned to the school year that first implements the reform. In all cases the econometric approach is based on a Cox proportional hazard model for lifetime duration.

One of the advantages of this research, as compared to previous studies relying on similar educational changes to identify the education gradient in life expectancy, is that the Swedish reform allows us to study two groups of people, born in the same years and active in the same labor markets, but having been educated by two different education systems at the same time. This allows us to use the econometric techniques described above rather than comparing across different birth cohorts or across groups of people brought up in different states that may differ in numerous ways. Compared to previous Swedish studies (such as Lager and Torssander, 2012 and Spasojevic, 2010) we use both Regression Discontinuity, and Difference in Differences, a much larger sample, a longer follow-up period and a larger set of outcome variables.

Our results show that, although the reform significantly elevated the educational attainment of the least skilled and increased the average years of schooling by more than a quarter of a year, it did not affect the life expectancy of those assigned to the new school system compared to the old one. Neither do we find an impact on hospitalization or drug use. This is despite a strong association between schooling and better health outcomes that we establish in our descriptive analysis.

\section{The Comprehensive School Reform}

\section{A. The Swedish School System before and after the Reform}

Prior to the implementation of the comprehensive school reform, pupils attended a common basic compulsory school (folkskolan) until grade six. After the sixth grade pupils were selected to continue either for one or, in mainly urban areas, two years in the basic compulsory school, or to attend the three year junior secondary school (realskolan). The selection of pupils into the two different school tracks was based on their past performance, measured by grades. The pre-reform compulsory school was in most cases administered at the 
municipality level. The junior secondary school was a prerequisite for the subsequent upper secondary school, which was itself required for higher education.

In 1948 a parliamentary committee proposed a school reform that implemented a new nineyear compulsory comprehensive school. ${ }^{2}$ The comprehensive school reform had three main elements:

1. An extension of the number of years of compulsory schooling to 9 years in the entire country.

2. Abolition of early selection in different schooling tracks based on academic ability. Although pupils in the comprehensive schools were able to choose between three tracks after the sixth grade - one track including vocational training, a general track, and an academic level preparing for later upper secondary school - they were kept in common schools and classes until the ninth grade. This is likely to have resulted in changes in the peer groups of pupils going through the reformed schooling system, leading to a broader of mix of students by SES and ability over a longer period of their schooling.

3. Introduction of a national curriculum. The pre-reform compulsory schools were administered by municipalities and the pre-reform curriculum varied between municipalities. The new national curriculum equalized academic standards across Sweden. While there is no direct evidence that the quality of schooling was affected by the reform, we cannot exclude the possibility that it changed.

\section{B. The Phased Introduction of the Reform}

The phased introduction of the reform, with the new comprehensive nine-year compulsory school, was viewed at the time as a social experiment, albeit not randomized. It started during an assessment period between 1949 and 1962, when the new curriculum was finalized. ${ }^{3}$ The proposed new school system, as described above, was introduced in municipalities or parts of city communities, which in 1952 numbered 1,055 (including 18 city communities).

\footnotetext{
2 The school reform and its development are described in Meghir and Palme (2005), Meghir et al (2012), and Holmlund (2007). Holmlund (2007) offers detailed analysis of the implementation of the reform and shows that, conditional on municipality fixed effects, there are no significant observable predictors of the timing of the reform. For more detailed reference on the reform, see Marklund (1981).

${ }^{3}$ The official evaluation was mainly of administrative nature. Details on this evaluation are also described in Marklund (1981).
} 
Municipalities could elect to implement the comprehensive school starting with first or fifth grade. Once the grade of implementation was fixed, all individuals from the cohort immediately affected and all subsequent cohorts went to comprehensive school. The older cohorts continued in the pre-reform school. Although many new schools were built as a consequence of the extension of compulsory schooling and municipalities were offered subsidized loans from the government to build schools (see Marklund, 1981), most of the post-reform schooling took place in the existing school buildings and the same teachers from the pre-reform system were used in the comprehensive school.

The phased-in introduction of the reform implied that the curricula of the pre- and postreform school systems were taught in parallel in the same schools. However, the post-reform children were always younger than the pre-reform ones and the post-reform system was never rolled back in any municipality. The pre-reform junior secondary schools that formed the academic track in the pre-reform school system, were phased out as a consequence of the reform. The school buildings were in some cases used for the last three grades in the new comprehensive school, but in many cases used for the expanding upper secondary schooling.

Figure 1 shows the take up rate of the experiment by cohort. It is evident from Figure 1 that the cohorts included in our empirical analysis, born between 1940 and 1957, cover the entire period of implementation of the comprehensive school. In 1962 it was decided that the new comprehensive school would become the standard education in Sweden. The last class that graduated from the old schooling system did so in 1970.

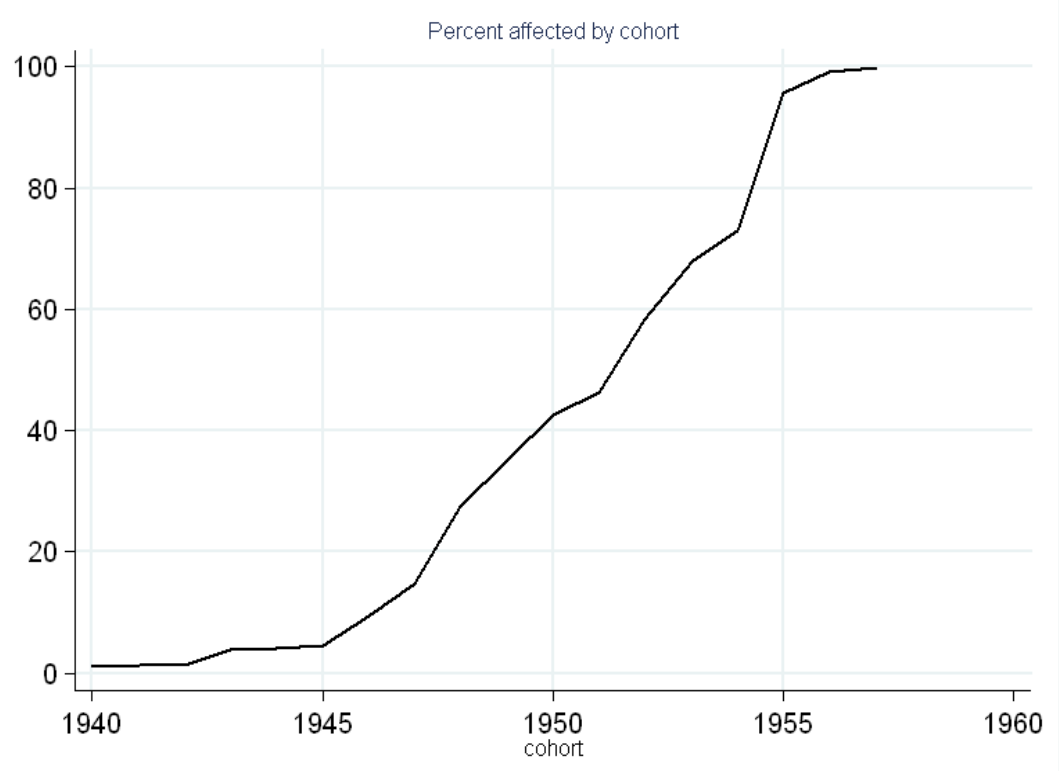

Figure 1 - Percentage SHARE OF BIRTH COHORT ASSIGNED TO THE POST REFORM (COMPREHENSIVE) SCHOOL SYSTEM. 
The selection of municipalities was not based on random assignment. However, the decision to select the implementing areas was based on an attempt to choose locations that were representative for the entire country, both in terms of demographics as well as geographically. In the first phase of the experiment a committee appointed by the National Board of Education chose municipalities from a pool of applicants in order to form a "representative" sample of municipalities. In later phases of the experiment the selection process became less strict.

Meghir and Palme (2005) and Holmlund (2007) study the effect of the comprehensive school reform on educational attainments. Meghir and Palme's (2005) estimates are based on individual reform assignment recorded in school registers. For their entire sample they find 0.252 additional years of education for males and 0.339 years for females; for low SES background persons the estimates are 0.3 extra years for males and 0.512 for females. Holmlund (2007) reports estimates in the range 0.21-0.61 additional years of schooling for men and 0.13-0.44 for women. ${ }^{4}$

\section{Data and the Association between Educational Attainments and Health}

The original sample was obtained from Statistic Sweden's Multiple Generation Register (see Statistics Sweden, 2012). ${ }^{5}$ We include all who were born in Sweden between 1940 and 1957 and who survived until the year they turn age 16. This sample resulted in $2,184,857$ observations (1,115,426 males and 1,069,431 females). We acquired data from the Population Census on church parish of birth, which was subsequently used to infer the municipality of birth and reform assignment, for 2,064,013 individuals from the original sample.

To assign date of reform assignment for each of the municipalities, i.e., the first birth cohort assigned to the reform, we use information on municipality of birth combined with an algorithm described in Holmlund (2007) and generously provided to us by Helena Holmlund. ${ }^{6}$ The original sources for date of implementation used by Holmlund are Marklund (1981) and various reports obtained by the National Board of Education (Skolöverstyrelsen) and listed by

\footnotetext{
4 Holmlund (2007) does not have individual treatment status and imputes it from municipality of residence in 1960.

5 All the register information described above was merged using the personal identification numbers by Statistics Sweden.

${ }^{6}$ The advantage of using municipality of birth as a basis of reform assignment - rather than municipality of residence, or self-reported reform status - is that it is not susceptible to parental choice of reform assignment, based on child ability. This could be achieved by moving to a municipality with a particular reform status corresponding to the year of birth of their child. There is also some evidence that that parents let their children live with relatives to avoid the reform if it was implemented in their municipality of living (see Marklund, 1981, or Meghir and Palme, 2005, for empirical evidence).
} 
Holmlund (2007). Since the reform was implemented by parts of the cities in Sweden's three largest cities - Stockholm, Gothenburg and Malmoe - and because we have no historical records on which cohorts were first affected in each of these parts, we have excluded those born in these cities from the data. This reduced the sample to 1,562,522 observations.

Our main outcome variable is mortality, which has the strong advantage that its reporting does not depend on individual behavior (as hospitalizations might, for example). For the purpose of context, male life expectancy in 2015 in Sweden was 80.7 years and female was 84 years. As far as our sample is concerned 25.4 percent of those not assigned to the reform were observed until death as well as 14.6 of those assigned. Of course, the latter group is on average younger. On average, individuals who went through the old schooling system have 11.4 years of schooling; those who went through the post-reform schools have 12 years. We show some basic descriptive statistics about the sample in Table 1 below.

TABLE 1 - DesCriptive STATISTICS.

\begin{tabular}{|c|c|c|}
\hline & Non-reform sample & Reform sample \\
\hline Total number of observations & 990,521 & 572,001 \\
\hline Share dead & 0.254 & 0.146 \\
\hline Share dead due to circulatory diseases & 0.063 & 0.031 \\
\hline Share dead due to cancer & 0.102 & 0.051 \\
\hline Share dead due to preventable diseases & 0.021 & 0.009 \\
\hline Share dead due to treatable diseases & 0.025 & 0.012 \\
\hline Average number of days in hospital care & 49.4 & 41.5 \\
\hline Average number of Rx Defined Daily Doses (DDD) & 9,127 & 6,736 \\
\hline Average number of years of schooling & 11.4 & 12.0 \\
\hline Observations including father's education & 823,947 & 523,907 \\
\hline $\begin{array}{l}\text { Share of fathers with no more than compulsory } \\
\text { schooling }\end{array}$ & 0.776 & 0.224 \\
\hline \multicolumn{3}{|c|}{ Sample with father's education } \\
\hline \multicolumn{3}{|l|}{ Sub-sample: Fathers with compulsory schooling } \\
\hline Share dead & 0.240 & 0.144 \\
\hline Average number of days in hospital care & 48.5 & 41.25 \\
\hline Average number of Rx Defined Daily Doses (DDD) & 9,246 & 6,920 \\
\hline Average number of years of schooling & 10.8 & 11.5 \\
\hline
\end{tabular}

Sub-sample: Fathers with more than compulsory schooling 
We use two further sets of health measures as outcomes: data on number of nights in hospital care obtained from the National in-patient register and data on all prescribed drugs obtained from the National prescription register. The National in-patient register contains information on duration and ICD codes for all hospital stays in Swedish hospitals. It has national coverage since 1987 and we have data through December 31, 2014. The National prescription register includes quantities, measured in defined daily doses, and ATC codes for all prescribed drugs in Sweden since 2005. We use data for the period until December 31, 2015.

Data on educational attainment for the father of the individual included in our sample was obtained from the 1970 census where only those aged 60 or younger were included. This restricts the sample to individuals with fathers born after 1910 when we report results by parental education $(1,347,854$ observations). Data on the individual's own education was obtained from the National Education Register included in the Integrated Database for Labour Market Research (LISA, see Statistics Sweden, 2011). ${ }^{7}$ Descriptive statistics including sample size are reported in the appendix.

We describe the association between mortality and education using a Cox proportional hazard model (see e.g. Cox and Oakes, 1984) as well as a linear probability model (LPM). With discrete duration data the hazard function at the heart of the Cox model is interpreted as the conditional probability of dying in the next age interval given survival to that age. This takes the form

$$
I_{i}(r \mid e d u c, T)=I_{0}(r) \exp \left\{\theta e d u c_{i}+\gamma^{\prime} T_{i}\right\}
$$

where, $r$ is duration to death (age), educ represents years of education and $T$ are cohort dummies (not reported). The function $I_{O}(r)$ is left unrestricted. This model is convenient because it is straightforward to control for censoring (due to survival at the end of the sample

\footnotetext{
7 The National Education register only provides information on individual level of education. To obtain Years of schooling, we use information on self-reported number of years of formal education for the relevant cohorts from the Swedish Level of Living surveys to impute average years of schooling corresponding to each level.
} 
period) and also naturally permits the analysis of competing risks, when considering alternative causes of death. The coefficient $\theta$ measures the change in mortality at each age associated with an extra year of education.

In column 1 of Table 2 we report $\exp (\theta)$, i.e. the ratio of the hazard for some level of education relative to the hazard with one year less of education. Thus no impact of education corresponds to a reported coefficient of one. A number below 1 is equivalent to a reduction in the hazard. We also report the association between years of education and the probability of dying in our sample period, using a linear probability model and controlling for cohort effects.

TABle 2 - MoRTAlity AND EDUCATION: MALES AND FEMALES AND By CAUSE.

\begin{tabular}{lccccc}
\hline & All causes & $\begin{array}{c}\text { Circulator } \\
\text { y diseases }\end{array}$ & Cancer & $\begin{array}{c}\text { Preventabl } \\
\text { e } \\
\text { diseases }\end{array}$ & $\begin{array}{c}\text { Treatable } \\
\text { Diseases }\end{array}$ \\
& & & & 4 & 5 \\
\hline & 1 & 2 & 3 & & \\
Years of Schooling, Cox & 0.9286 & 0.9044 & 0.9578 & 0.9011 & 0.8894 \\
& $(0.0005)$ & $(0.0010)$ & $(0.0008)$ & $(0.0018)$ & $(0.0017)$ \\
Years of Schooling, LPM & -0.0125 & -0.0042 & -0.0029 & -0.0015 & -0.0019 \\
& $(0.0001)$ & $(0.0001)$ & $(0.0001)$ & $(0.00003)$ & $(0.00003)$ \\
& & & & & \\
Dead, percent & 19.98 & 4.98 & 8.15 & 1.66 & 1.95 \\
Number of deaths & 364,468 & 90,867 & 148,733 & 30,323 & 35,619 \\
$N$ & $1,823,901$ & $1,823,901$ & $1,823,901$ & $1,823,901$ & $1,823,901$ \\
\hline
\end{tabular}

Note: Indicator variables for gender as well as year of birth dummies included in the specification.

In columns 2 and 3 we report results using independent competing risks models for the two main causes of death in the sample: circulatory diseases, cancer and other. We repeat the exercise by reclassifying the diseases as "preventable", "treatable" and "other". ${ }^{8}$ The preventable causes of death may reflect health behaviors and investments and the treatable ones may reflect access to healthcare.

The association between mortality and education is statistically very strong: the first column in Table 2 shows that an additional year of schooling is associated with a 7 percentage point reduction in the mortality rate. This translates to an increase in life expectancy associated with a year of education of 3.75 months for our observation window (16-75 years of age). ${ }^{9}$ It also corresponds to a decline in the probability of dying of 0.0125 for each extra year of schooling

\footnotetext{
8 Circulatory diseases are defined as ICD-10: C Chapter and cancer as ICD-10: I Chapter in the Swedish Cause of Death Registry. Appendix Table A1 reports how these are classified using the ICD codes available in the data.

9 This estimate is obtained by integrating the difference between the baseline hazard and the prediction obtained by calculating $S\left(t \mid x_{k}\right)=S_{0}{ }^{\exp \left(\beta x_{k}\right)}$, where $\exp \left(\beta x_{k}\right)$ is the hazard ratio estimate for years of schooling, ie., 0.9286 (see Cleves et al., 2004).
} 
within our sample as shown by the linear probability model. As a benchmark, for the cohorts under consideration life expectancy overall has been estimated to have increased by 1.6 years and average schooling increased by 2.4 years. If the reported association reflected a causal impact, the increase in education would have accounted for 47 percent of the increase in life expectancy. The remaining columns show that the effect is largest for circulatory diseases but similar for treatable and preventable diseases.

In the appendix (Tables A3 and A4) we show how education is related to days of hospitalization and to the use of prescription drugs. Overall, an extra year of education is associated with fewer days in hospital (-1.9 with SE of 0.035). Interestingly, an extra year of schooling is associated with a 0.6 percentage point reduction in pain relief medication usage and 0.33 percentage point reduction in the use of antidepressants, an issue of relevance given the opioid epidemic in the US.

The implication from this section is clear: there is a very strong statistical association between improved health and education, even in a high income country such as Sweden, with its strong welfare system and almost universal access to high quality healthcare. The key question is, of course, whether there is a causal link.

\section{Empirical Strategy for estimating the effect of the educational reform}

To estimate the impact of the reform on our various outcomes we use two approaches. The first is based on a difference in differences (DiD) design and the second is based on regression discontinuity (RD).

The DiD design exploits the fact that individuals in the same birth cohort were either exposed to the educational reform or not, depending on which municipality they lived in. For some of the outcomes, namely years of education, days of hospitalization, indicators for hospitalization for various diseases and for prescription drugs we use the standard linear difference in differences model. In our DiD specifications we include a dummy variable for gender, a full set of dummies for municipality of birth, a full set of cohort dummies, separate linear trends for each municipality of birth and, finally, an indicator of whether the individual was assigned to the reform.

To examine the effects of mortality we use both a linear probability model (as is standard in DiD specifications) where the outcome is death in any year the person is observed in the sample. We also use a Cox proportional hazard model for the duration of life again based on 
the DiD assumption to identify the effect. The index function is the same in both specifications. However, in the Cox proportional hazard model we stratify on municipality of birth. This means that we allow for different baseline hazard in each municipality of birth, which is more flexible than simply including separate dummy variables for each municipality. Also, rather than including separate linear trends for each of the about 1,000 different municipalities of birth, we estimate separate linear trends for each group of municipalities, grouped by the year they implemented the reform. ${ }^{10}$

As Altonji and Blank (1999) and Athey and Imbens (2006) point out the DiD approach does not require linearity. The assumptions required are that (i) the outcome variable in the untreated state is related to unobservable heterogeneity in a strictly monotonic fashion; (ii) the distribution of this unobservable must be time invariant, but may depend on the group to which the individual belongs (here the municipality); and (iii) conditional on a value for this unobservable, growth of the outcome in the absence of treatment is assumed independent of group, which is the usual common growth assumption. ${ }^{11}$ The linear model is just a special case of this.

Based on these ideas, and while a nonparametric analysis is in principle possible (as shown in Athey and Imbens, 2006) we take the simpler route of using the Cox proportional hazard model. ${ }^{12}$ This allows us to deal with censoring and with competing risks when we look at death by cause. We also show results using the standard linear probability model where the outcome is mortality over the sample period, as in the descriptive analysis. This is a standard linear DiD regression.

Similarly to the descriptive analysis, for the Cox model the hazard function at duration of life $r$ takes the form

(2) $I_{1, i, m, t}(r \mid X)=I_{0, m}(r) \exp \left\{\beta R_{i, m, t}+\gamma_{0} F_{i}+\gamma_{1}^{\prime} T_{i}+\gamma_{2}^{\prime} G_{i} * C_{i}\right\}$,

where $i, m$ and $t$ are sub-indices for individual, municipality and birth cohort, respectively; the function $I_{o m}(r)$ varies freely by municipality and age; $R$ indicates whether the individual was assigned to the reform or not based on municipality of birth and cohort; $T$ is a vector of dummy variables for cohort of birth; $F$ is a dummy variable for female; $G$ is a vector of dummy variables indicating the first cohort to implement the post-reform school system in the individual's municipality of birth and $C$ is the individual's year of birth. Thus the $G_{i}{ }^{*} C_{i}$ term

\footnotetext{
10 Given the nonlinear nature of this approach adopting 1000 separate trends would be computationally infeasible.

11 If the outcome variable is discrete then point estimates require a functional form assumption - most people use the linear probability model when they have a binary outcome - however this is just one possible identifying assumption.

12 The nonparametric approach is particularly complicated by the large number of treatment and comparison groups and the numerous periods.
} 
allows for differential trends by municipality groups classified by the year in which they implemented the reform. The 1000 or so municipality fixed effects are absorbed by the baseline hazard, which is different for each municipality and is not specified parametrically. ${ }^{13}$ The coefficient $\beta$ measures the effect of the reform on mortality. By using these various approaches, we hope to improve confidence in the results.

When we consider death by different causes we use the independent competing risks models. ${ }^{14}$ The hazard function for each cause of death takes the same form as above.

This approach identifies the impact by comparing growth in the outcome variable across municipalities. An alternative approach is to identify the effect of the reform within municipalities based on a regression discontinuity design where we use the threshold date that determines in which year the child will start attending school - $1^{\text {st }}$ January in Sweden. Anyone born on or after that date in the calendar year of the reform implementation is assigned to the reform. Before that date they are assigned to the previous school year and, as a result, to the old schooling system. Ideally we would use a very narrow window around the discontinuity, comparing outcomes of people born just before the cutoff date and those born just after; however this would lead to too small a sample. Instead of restricting the bandwidth, we use polynomials in the month-distance from the discontinuity (one before and one after) combined with dummy variables to control for month of birth effects. The assumption is that these polynomials control for any outcome-relevant differences for people born just before or after the break point. In addition, the discontinuity is "fuzzy" in the sense that some people may relocate their children to a different entry cohort than the one they are strictly assigned to. In an attempt to further alleviate the potential effects of selective cohort placement we assign individuals to the reform based on their municipality of birth and their date of birth, akin to an intention to treat design.

The specification we use for the hazard in this case is

$I_{1, i, m, t}(r \mid X)=I_{0}(r) \exp \left(\beta_{1} R_{i, m, t}+\gamma_{1} W_{i}+\gamma_{2} W_{i}^{2}+\gamma_{3} W_{i} R_{i, m, t}+\gamma_{4} W_{i}^{2} R_{i, m, t}+\delta T_{i}+\theta Z_{i}\right)$

where $W$ is a variable measuring the time in months to January $1^{\text {st }}$ which is the cutoff date for determining the school-year for the $i$ th individual, ${ }^{15} T_{i}$ is a full set of dummy variable for cohort of birth, $Z_{\mathrm{i}}$ includes a dummy variable for gender as well as a full set of dummy

\footnotetext{
13 This model satisfies the assumptions stated by Athey and Imbens (2006) for nonlinear DiD models. A similar parametric approach in the context of nonlinear DiD models was followed by Blundell, Dias, Meghir and van Reenen (2004).

14 See Honoré and Lleras-Muney (2006) among others, on the identifiability of a competing risks model with dependent risks.

${ }^{15} \mathrm{~W}$ is zero at the cutoff, negative before and positive after.
} 
variables for month of birth to control for seasonal effects in time of birth (see Dobkin and Fereira, 2010). In the estimation we included successively higher order polynomials until the additional terms became insignificant. In all cases, a second order polynomial turned out to be sufficient. ${ }^{16}$ We can interpret the coefficient $\beta_{1}$ as the impact of the reform averaged across discontinuities. In the appendix we also present results based on the linear probability model using this discontinuity design. The conclusions do not change.

Both empirical approaches (DiD and RD) control for time-invariant differences between the treated and the comparison groups. Both have a causal interpretation under our assumptions but they may relate to different sub-populations and if the effects are heterogeneous the results may differ.

Throughout, we present results for males and females separately because they are expected to follow different underlying health processes. Since the reform had a stronger effect for those with low educated fathers (see Meghir and Palme, 2005 and below), we also break down the results by father's education. We refer to those whose father had just compulsory education as low socio-economic status (SES) and the rest as high SES.

\section{Results}

\section{A. Effects of the Reform on Educational Attainment}

In Table 3 we start by presenting the impact of the reform on years of education. ${ }^{17}$ The results are broken down by father's education and shown for males and females combined as well as separately. The standard errors for all results are clustered at the municipality level.

The sets of estimates from the two approaches are in general very similar. The reform led to an increase of about 0.25 of a year in education. The effect is substantially larger for the low SES group than and higher for males than for females. More detailed results including impacts by level of education and the sample sizes for all comparisons are presented in Appendix Table A2.

\footnotetext{
16 In addition, Gelman and Imbens (2014) recommend to not use higher order polynomials in order to avoid over-fitting.

17 This has been documented elsewhere for different samples (Meghir and Palme, 2005; Meghir et al, 2012), but not on this sample.
} 
TABLE 3 - DID AND RD ESTIMATES OF THE IMPACT OF THE COMPREHENSIVE SCHOOL REFORM ON YEARS OF SCHOOLING.

\begin{tabular}{lccc}
\hline & $(1)$ & $(2)$ & $(3)$ \\
Males and Females (Difference in Differences) & All & Low SES & High SES \\
\cline { 2 - 4 } & 0.255 & 0.304 & 0.086 \\
Males (Difference in Differences) & $(0.015)$ & $(0.017)$ & $(0.024)$ \\
& 0.301 & 0.363 & 0.086 \\
Females (Difference in Differences) & $(0.018)$ & $(0.021)$ & $(0.035)$ \\
& 0.205 & 0.238 & 0.086 \\
Males and Females (Regression Discontinuity) & $(0.021)$ & $(0.024)$ & $(0.035)$ \\
& 0.241 & 0.300 & 0.068 \\
Males (Regression Discontinuity) & $(0.029)$ & $(0.028)$ & $(0.037)$ \\
& 0.313 & 0.375 & 0.081 \\
Females (Regression Discontinuity) & $(0.023)$ & $(0.033)$ & $(0.050)$ \\
& 0.177 & 0.217 & 0.055 \\
& $(0.031)$ & $(0.032)$ & $(0.047)$ \\
\hline
\end{tabular}

Notes: Each number represents an impact from a separate regression by method and demographic group. DiD specification includes a full set of dummy variables for year of birth and municipality of birth as well as separate linear trends for municipalities of birth. RD specification includes separate quadratic polynomials in the running variable before and after the break point, a dummy variable for gender as well as a full set of dummy variables for month of birth. The samples of low and high SES background men and women do not add up to the aggregate sample size because of missing information on father's education in the registry data. Standard errors are in parentheses and are clustered by municipality of birth.

Finally, Figure 2 illustrates the effect graphically. The upper two panels illustrate the RD models. The left panel refers to the proportion attending the pre-reform compulsory level of education, while the right panel shows the years of education. Each dot in the figures represents the average outcome by month of birth on the basis of distance from the first month-of-birth cohort assigned to the reform in each municipality. ${ }^{18}$ The regressions discontinuity estimates shown in Table 3 can be obtained using weighted least squares on the collapsed data shown in the upper panels of Figure 2.

For each outcome there is a marked jump at the first cohort assigned to the reform. However, the figures also show apparent trends pre-reform towards higher educational attainment. The main reason for this overall trend in the graph is a composition effect: groups of observations (dots) that are distant from the discontinuity and to the left will represent more municipalities that delay the reform, which is correlated with lower schooling. This feature is controlled for in the regression analysis and does not obscure the fact that there is a clear break at the time of the reform in the municipality.

\footnotetext{
18 That is, if the first cohort in a municipality to be assigned to the reform was those born in January 1948, those who were born in, say, April 1949, are born 15 months after the first month of birth cohort in that municipality. Correspondingly, those born in January 1947 are born 12 months before the first ones assigned to the reform. To the right of zero on the horizontal-axis we have the treated group and to the left the comparison group.
} 
The lower panels of Figure 2 show the average residuals from a DiD model where we have excluded the reform indicator. The left panel relates to the share attending the pre-reform compulsory school, while the right relates to years of education. The jump in schooling associated with the reform is evident here as well.
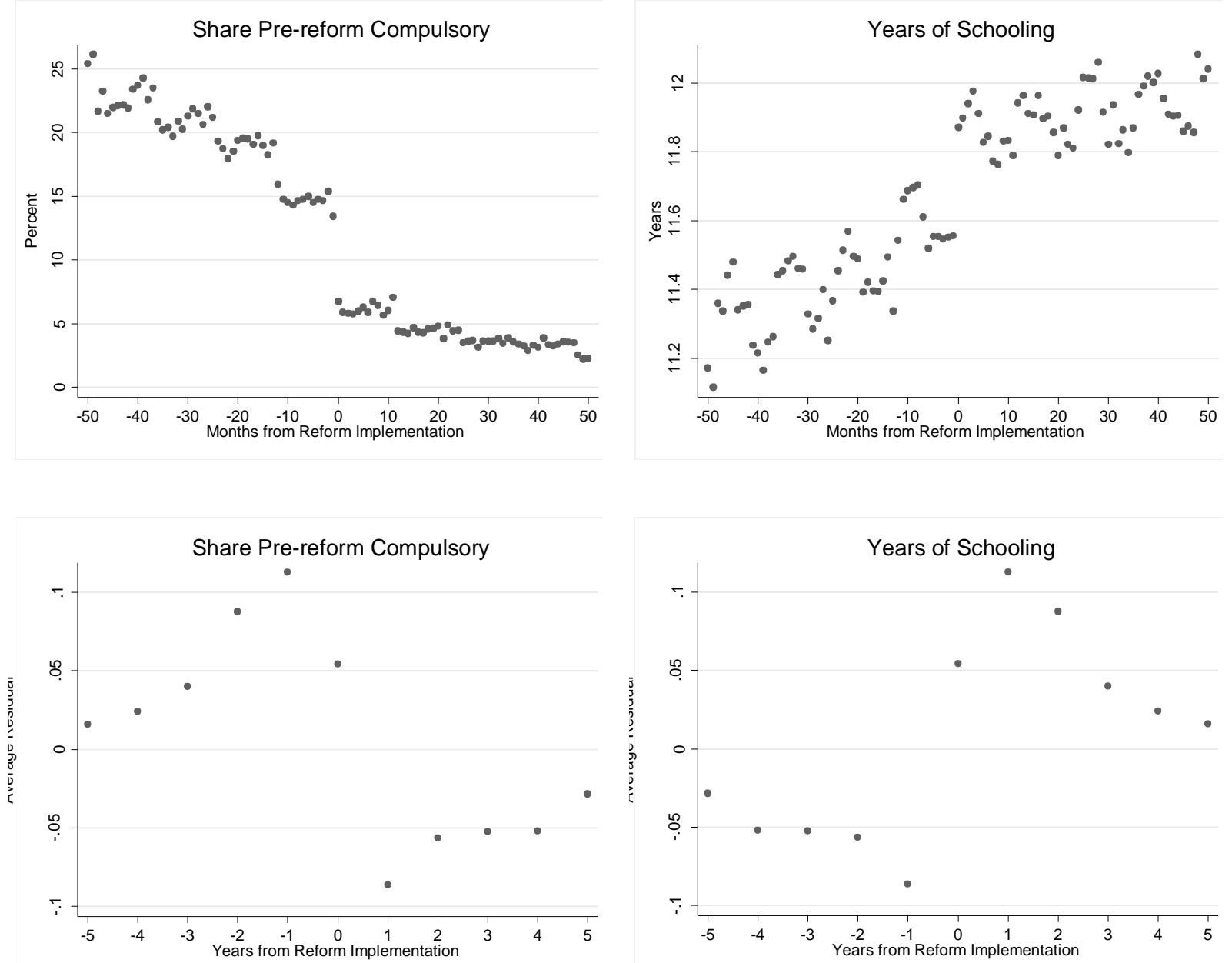

FIGURE 2. EFFECT OF THE REFORM ON FINAL EDUCATIONAL ATTAINMENTS. NOTES TO FIGURE: UPPER LEFT PANEL: SHARE WITH YEARS OF FINAL EDUCATION LESS THAN OR EQUAL TO THE PREREFORM COMPULSORY LEVEL; UPPER RIGHT PANEL: YEARS OF SCHOOLING; LOWER LEFT PANEL: RESIDUALS FROM A LINEAR PROBABILITY DID MODEL EXCLUDING THE REFORM INDICATOR USING AN INDICATOR FOR EDUCATIONAL ATTAINMENTS MORE THAN THE PRE-REFORM COMPULSORY LEVEL AS DEPENDENT VARIABLE; LOWER RIGHT PANEL: RESIDUALS FROM A OLS DID MODEL EXCLUDING THE REFORM INDICATOR USING YEARS OF SCHOOLING AS DEPENDENT VARIABLE. THE HORIZONTAL AXIS FOR THE TOP (BOTTOM) TWO PANELS IS THE NUMBER OF BIRTH MONTHS (YEARS) FROM THE FIRST COHORT FOR WHICH THE REFORM WAS IMPLEMENTED (THE ZERO POINT). NEGATIVE NUMBERS REPRESENT PRE-IMPLEMENTATION COHORTS AND POSITIVE ONES POST IMPLEMENTATION. 
Appendix Figure A1 displays the same graphs as the top panel in Figure 2 by father's education. ${ }^{19}$ It is apparent from these figures that the effect of the reform is much stronger for all outcomes in the low SES group.
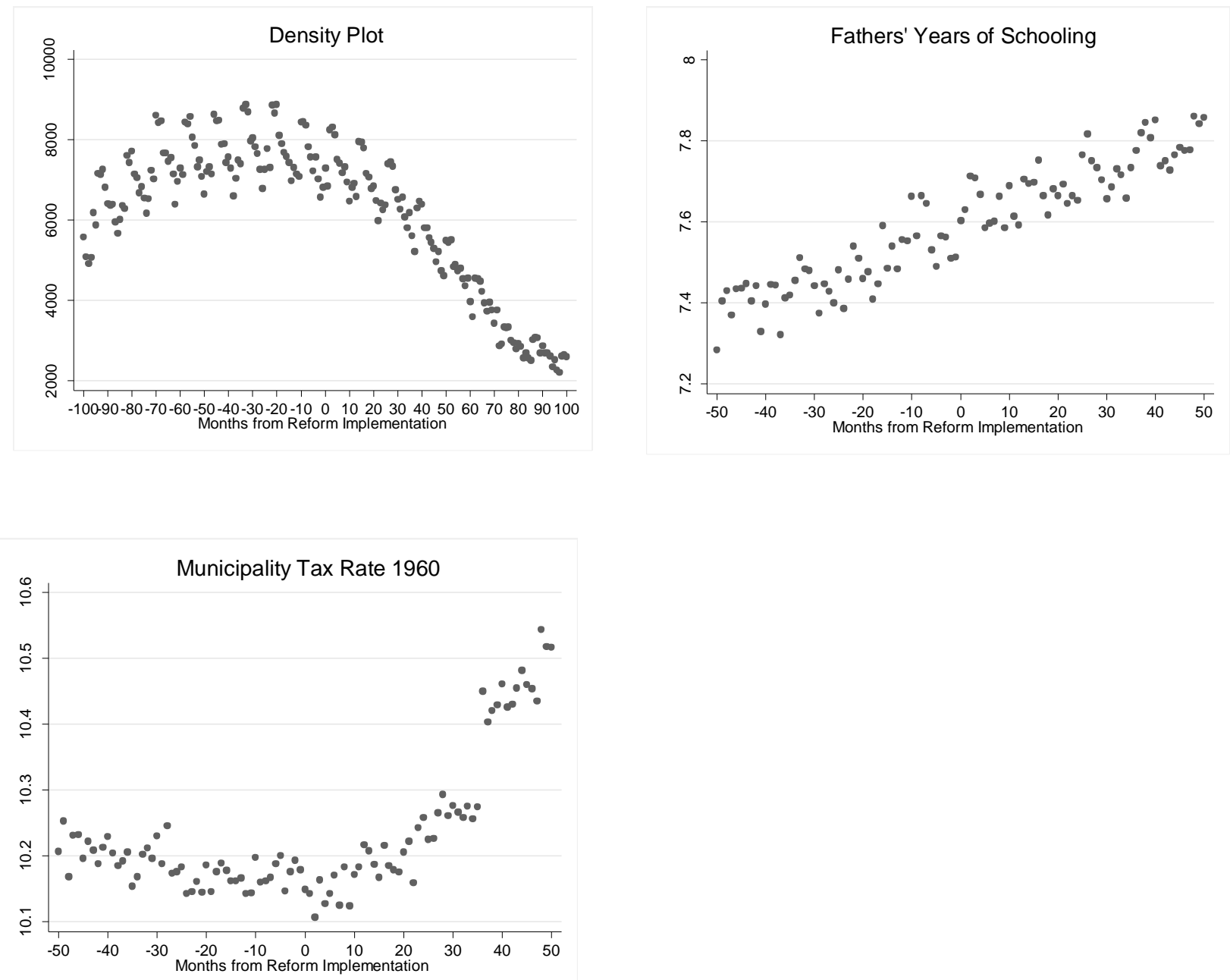

Figure 3. Diagnostic tests. Notes to Figure: Top left PANEL: Density of OBSERVATIONS BY MONTHS BEFORE THE REFORM. TOP RIGHT PANEL: PLACEBO TEST 1 - THE DISCONTINUITY AND FATHER'S EDUCATION. BOTTOM LEFT PANEL: PLACEBO TEST 2 - THE DISCONTINUITY AND MUNICIPALITY TAX RATE. THE HORIZONTAL AXIS AS IN FIGURE 2.

19 Individuals whose father had statutory schooling or less are labeled low SES. The rest are high SES. 


\section{Diagnostics}

Before proceeding, we show some validation tests for the regression discontinuity. The results from these tests are shown in Figure 3. The most robust model is obtained if we only include observations very close to the breakpoint. However, as the graph in the top left panel shows the parameter does not change significantly when we extend the width of the window over which estimation takes place.

The top right panel of Figure 3 shows the result from a density test suggested by McCrary (2008). The density plot shows no indication of a sudden change in the density of observations for date of birth just before or just after the discontinuity point; this illustrates that there is no significant manipulation of the date of birth, the running variable, on which our classification relies.

Finally, the lower two panels show that there is no "impact" on variables that should not be affected by the reform, namely the education of the father and the municipality tax rate. ${ }^{20}$ Similar placebo tests with other observables yield the same result (see Appendix Figure A2). These tests illustrate the robustness of our approach. We now proceed with the central results of interest.

\section{B. Effects on Mortality}

Consider first the same type of graphs we just showed for education, but for mortality. The left panel of Figure 4 shows raw mortality rates by distance in months from the cutoff date of reform implementation. The upper panel shows the results for the entire sample and the lower panel the corresponding ones for low and high SES individuals, respectively. There is a negative slope in all graphs reflecting the fact that individuals are getting younger along the horizontal axis. However, there is no large or significant break in this trend at the cutoff date.

The right panel of Figure 4 shows the residuals from the linear probability DiD models with an indicator for having died before the end of the follow up period as dependent variable and excluding the reform indicator from the specification. These results provide further visual

\footnotetext{
20 These were obtained from the multigenerational register and from the Yearbook of Swedish Municipalities 1960 respectively. They were linked to our data through the municipality identification number.
} 
evidence that the reform had no effect on mortality. We then confirm these with the regression results, using both $\mathrm{DiD}$ and $\mathrm{RD}$ approaches.

Table 4 shows the results from four different specifications estimating the effect of the schooling reform on mortality. Two are based on the DiD framework and the specification shown in Equation (1) and two on the RD specification in Equation (2). Each of these models is estimated using both Cox regressions and the linear probability models (LPM). The first panel combines males and females and the two lower panels show results by gender. 

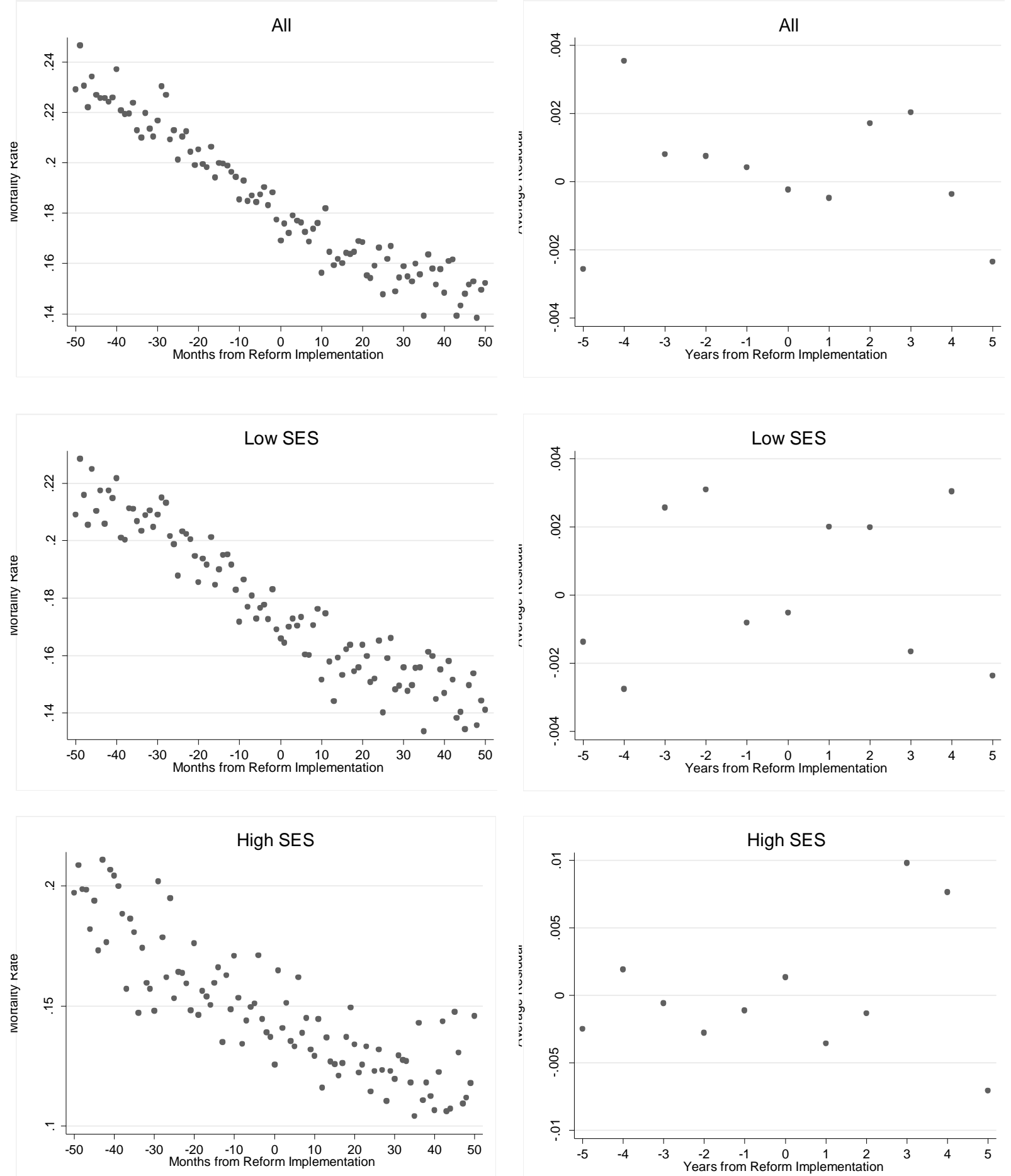

FIGURE 4. REFORM EFFECT ON MORTALITY. NOTES TO FIGURE: LEFT PANEL: AVERAGE MORTALITY RATE BY DISTANCE IN MONTHS FROM REFORM IMPLEMENTATION. RIGHT PANELS: RESIDUALS FROM A LINEAR PROBABILITY DID MODEL EXCLUDING THE REFORM INDICATOR. UPPER PANELS: POPULATION. MIDDLE PANELS: LOW FAMILY SES. LOWER PANELS: HIGH FAMILY SES. Y-AXIS MEASURES THE WITHIN CELL MORTALITY RATE (NOT AGE-ADJUSTED) OVER THE OBSERVED PERIOD. THE HORIZONTAL AXIS MEASURES THE NUMBER OF MONTHS BETWEEN THE MONTH OF BIRTH FOR THE INDIVIDUALS INCLUDED IN THE CELL AND THE MONTH OF BIRTH OF THE FIRST COHORT OF INDIVIDUALS AFFECTED BY THE REFORM. 
The estimates shown in Table 4 imply no effect of the reform on mortality: the hazard ratio is not significantly different from one either for the $\mathrm{DiD}$ estimates or for the $\mathrm{RD}$ ones and the LPM estimates are not significantly different from zero. The general result is supported by the fact that it is robust to the choice of econometric model and that it holds within each subgroup under study - even within the group of men from low SES families, where we estimated the largest effect of the reform on educational attainment. In Section 6, we discuss the magnitude of these effects and how large they could be potentially, if one takes into account the width of the confidence interval. In Appendix Table A5 we also show that the impact of the reform is zero at all ages in our observation window (44-70). 
TABLE 4 - THE EFFECTS OF EDUCATION REFORM ON MORTALITY. COX PROPORTIONAL HAZARD REGRESSIONS AND REGRESSION DISCONTINUITY ESTIMATION RESULTS.

\begin{tabular}{|c|c|c|c|}
\hline & $\begin{array}{l}(1) \\
\text { All }\end{array}$ & $\begin{array}{c}(2) \\
\text { Low SES }\end{array}$ & $\begin{array}{c}(3) \\
\text { High SES }\end{array}$ \\
\hline \multicolumn{4}{|c|}{ Males and Females } \\
\hline DiD, LPM & $\begin{array}{l}0.0006 \\
(0.0017)\end{array}$ & $\begin{array}{l}0.0019 \\
(0.0019)\end{array}$ & $\begin{array}{c}-0.0012 \\
(0.0036)\end{array}$ \\
\hline $\mathrm{DiD}, \mathrm{Cox}$ & $\begin{array}{r}1.0005 \\
(0.0105)\end{array}$ & $\begin{array}{c}1.0058 \\
(0.0128)\end{array}$ & $\begin{array}{c}1.0071 \\
(0.0281)\end{array}$ \\
\hline RD, LPM & $\begin{array}{l}-0.00052 \\
(0.00223)\end{array}$ & $\begin{array}{c}0.00091 \\
(0.00249)\end{array}$ & $\begin{array}{c}0.00102 \\
(0.00456)\end{array}$ \\
\hline RD, Cox Regression & $\begin{array}{c}0.9990 \\
(0.0135)\end{array}$ & $\begin{array}{c}1.0088 \\
(0.0160)\end{array}$ & $\begin{array}{c}1.0057 \\
(0.0337)\end{array}$ \\
\hline $\begin{array}{l}\mathrm{N} \\
\text { Deaths }\end{array}$ & $\begin{array}{c}1,562,493 \\
335,085\end{array}$ & $\begin{array}{c}1,051,462 \\
216,861\end{array}$ & $\begin{array}{c}296,392 \\
45,406\end{array}$ \\
\hline \multicolumn{4}{|c|}{ Males } \\
\hline DiD, LPM & $\begin{array}{l}-0.0003 \\
(0.0024)\end{array}$ & $\begin{array}{l}-0.0001 \\
(0.0028)\end{array}$ & $\begin{array}{c}0.0014 \\
(0.0054)\end{array}$ \\
\hline DiD, stratified Cox & $\begin{array}{c}0.9841 \\
(0.0144)\end{array}$ & $\begin{array}{c}0.9933 \\
(0.0161)\end{array}$ & $\begin{array}{c}1.0189 \\
(0.0371)\end{array}$ \\
\hline RD, LPM & $\begin{array}{l}-0.0017 \\
(0.0034)\end{array}$ & $\begin{array}{l}-0.0008 \\
(0.0036)\end{array}$ & $\begin{array}{c}0.0040 \\
(0.0070)\end{array}$ \\
\hline RD, Cox Regression & $\begin{array}{c}0.9937 \\
(0.0176)\end{array}$ & $\begin{array}{c}1.0001 \\
(0.0201)\end{array}$ & $\begin{array}{c}1.0214 \\
(0.0465)\end{array}$ \\
\hline $\begin{array}{l}\mathrm{N} \\
\text { Deaths }\end{array}$ & $\begin{array}{l}812,719 \\
203,906\end{array}$ & $\begin{array}{l}545,523 \\
131,318\end{array}$ & $\begin{array}{c}152,782 \\
27,400\end{array}$ \\
\hline \multicolumn{4}{|c|}{ Females } \\
\hline DiD, LPM & $\begin{array}{c}0.0015 \\
(0.0021)\end{array}$ & $\begin{array}{c}0.0040 \\
(0.0024)\end{array}$ & $\begin{array}{l}-0.0034 \\
(0.0044)\end{array}$ \\
\hline DiD, stratified Cox & $\begin{array}{c}1.0125 \\
(0.0158)\end{array}$ & $\begin{array}{c}1.0295 \\
(0.0203)\end{array}$ & $\begin{array}{c}0.9926 \\
(0.0390)\end{array}$ \\
\hline RD, LPM & $\begin{array}{c}0.0007 \\
(0.0026)\end{array}$ & $\begin{array}{c}0.0025 \\
(0.0032)\end{array}$ & $\begin{array}{l}-0.0020 \\
(0.0053)\end{array}$ \\
\hline RD, Cox Regression & $\begin{array}{c}1.0072 \\
(0.0184)\end{array}$ & $\begin{array}{c}1.0224 \\
(0.0243)\end{array}$ & $\begin{array}{c}0.9841 \\
(0.0450)\end{array}$ \\
\hline$N$ & 749,702 & 505,939 & 143,610 \\
\hline Deaths & 131,179 & 85,543 & 18,006 \\
\hline
\end{tabular}

Notes: Each number represents an impact from a separate regression by method and demographic group. Standard errors are in parentheses and are clustered by municipality of birth. DiD LPM specification includes a full set of dummy variables for year of birth and municipality of birth as well as separate linear trends for municipalities of birth. Stratified Cox regressions include year of first implementation specific linear trends. RD specification includes separate quadratic polynomials in the running variable before and after the break point, a dummy variable for gender as well as a full set of dummy variables for month of birth. The samples of low and high SES background men and women do not add up to the aggregate sample size because of missing information on father's education in the registry data. Standard errors are in parentheses and are clustered by municipality of birth. 


\section{Effects by Cause of Death}

We now turn to two alternative classifications of diseases to see whether mortality declined from causes that may be more explicitly related to behavior. ${ }^{21}$ We first consider mortality from circulatory diseases (strongly correlated with education) and cancer (the single most important cause of death in the age group we study), with other causes of death acting as censoring.

The results are shown in Table 5 and as is evident from the first column, the effects are not significant at the $5 \%$ level for either circulatory diseases or cancer. ${ }^{22}$ Some marginally significant effects for the high SES group are easily discounted, once we take into account that the $p$-values need to be adjusted for testing multiple hypotheses. These results can be confirmed visually in the various plots presented in Appendix Figure A3.

21 Appendix Table A1 reports how these are classified using the ICD codes available in the data.

${ }^{22}$ We only present results for males and females combined and we concentrate on the sample that excludes the three main cities. Results for the two gender groups separately are shown in Table A4 in the Appendix. 
TABLE 5 - THE EFFECTS OF EDUCATION REFORM ON MORTALITY BY CAUSE OF DEATH. CIRCULATORY DISEASES AND CANCER CAUSES OF DEATH ONLY. COX PROPORTIONAL HAZARD COMPETING RISK ESTIMATES AND RD MODEL ESTIMATES. POPULATION OF SWEDES BORN 19401957.

(1)

All

\begin{tabular}{lccc} 
& All & Low SES & High SES \\
\hline & & & \\
Reform, stratified Cox & 1.0122 & Circulatory diseases & 0.9382 \\
& $(0.0232)$ & 1.0098 & $(0.0463)$ \\
Reform, RD & 0.9992 & $(0.028)$ & 0.9671 \\
& $(0.0319)$ & 0.9941 & $(0.0664)$ \\
& & $(0.0356)$ & 9,881 \\
Deaths & 80,616 & 52,950 & \\
& & Cancer & 0.9756 \\
Reform, stratified Cox & 0.9882 & 1.0117 & $(0.0337)$ \\
& $(0.0173)$ & $(0.0209)$ & 0.9006 \\
Reform, RD & 0.9744 & 1.0065 & $(0.0286)$ \\
& $(0.0218)$ & $(0.0290)$ & 18,103 \\
Deaths & & & 296,392 \\
$\mathrm{~N}$ & 129,577 & 87,329 & $1,051,462$ \\
\hline \multicolumn{2}{l}{ Notes: Each cell presents the estimate from a separate regression by method and demographic group. Standard }
\end{tabular}

Notes: Each cell presents the estimate from a separate regression by method and demographic group. Standard errors are in parentheses and are clustered by municipality of birth. DiD Stratified Cox regressions include year of first implementation-specific linear trends. RD specification includes separate quadratic polynomials in the running variable before and after the break point, a dummy variable for gender as well as a full set of dummy variables for month of birth. The samples of low and high SES background men and women do not add up to the aggregate sample size because of missing information on father's education in the registry data.

In Appendix Table A6 we also demonstrate that the reform did not result in significant reductions in mortality from preventable or treatable diseases. Appendix Figure A3 shows the corresponding plots by causes of death.

\section{Hospitalization}

As we discussed in Section 3, a possible limitation of mortality as a measure of adult health is that we are not able to observe entire life histories and effects of education on health could potentially show up later in life. Moreover, the reform could have improved health in ways that affects the quality of life but not necessarily its length. Therefore, in addition to mortality, we also use hospitalization and consumption of prescribed drugs as health outcomes. For hospitalization we use three different measures: total number of days in hospital care as well as binary indicators for having ever been hospitalized for cancer, circulatory and respiratory diseases. The regressions used here are linear DiD or linear RD regressions with a quadratic 
polynomial in the time from the reform. The coefficient is thus interpreted as the effects of the reform on days of hospitalization.
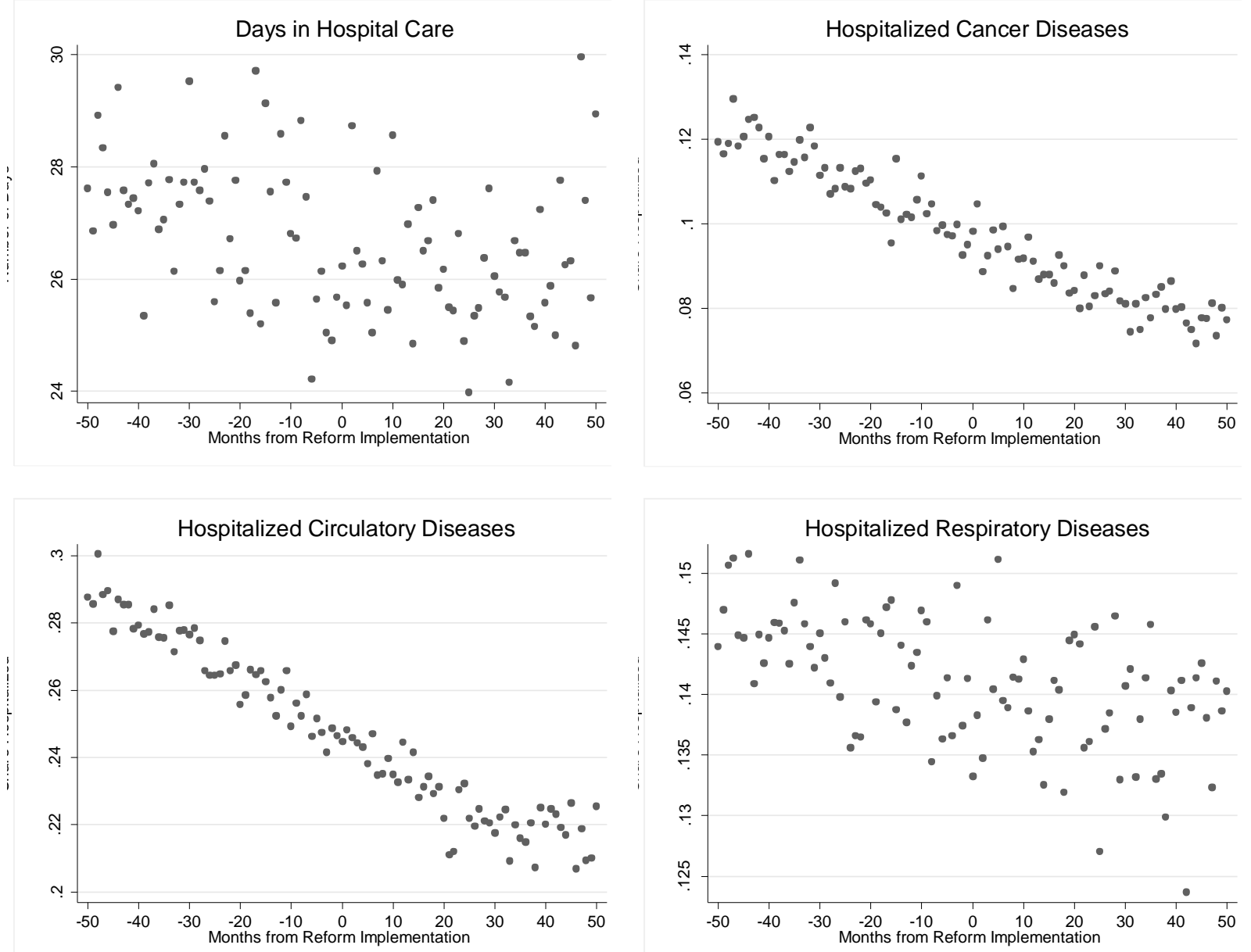

FIGURE 5. REFORM EFFECT ON HOSPITALIZATION. TOTAL NUMBER OF DAYS IN HOSPITAL CARE AND INDICATORS FOR HOSPITAL STAY BY MAIN DIAGNOSIS. NOTES TO FIGURE: THE HORIZONTAL AXIS MEASURES THE NUMBER OF MONTHS BETWEEN THE MONTH OF BIRTH FOR THE INDIVIDUALS INCLUDED IN THE CELL AND THE MONTH OF BIRTH OF THE FIRST COHORT OF INDIVIDUALS AFFECTED BY THE REFORM.

Note: $y$-axis measures the within cell share (not age-adjusted) of the population hospitalized for at least one night between 1987 and 2014.

The results are shown graphically in Figure 5. There are no apparent effects of the reform for any of the four outcomes. This assessment is further confirmed in Table 6, which shows the regression results from both $\mathrm{DiD}$ and RD specifications. None of the 24 estimates - by model, outcome or group - are statistically different from zero. 
TABLE 6 - THE EFFECTS OF EDUCATION REFORM ON HOSPITALIZATION. TOTAL NUMBER OF DAYS IN HOSPITAL CARE AND INDICATORS FOR HOSPITAL STAY BY MAIN DIAGNOSIS. OLS AND LPM REGRESSIONS. MEN AND WOMEN.

(1)

All

(2)

Low SES

Number of Days

Reform, DiD

0.2093

(0.3117)

Reform, RD
0.2618

(0.33913)

0.0579

(0.4549)
(3)

High SES

(0.3726)

27.10

27.34

Mean dep var
Reform, DiD

Cancer

Reform, RD

0.0008

$-0.0006$

0.0052

(0.0011)

(0.0013)

(0.0023)

0.0006

$-0.0009$

0.0056

(0.0016)

(0.0018)

(0.0028)

$(0.5867)$

0.2812

(0.7631)

Mean dep var

0.1104

0.1122

0.1020

\begin{tabular}{lccc}
\hline & & Circulatory Diseases \\
Reform, DiD & 0.0022 & -0.0004 & 0.0045 \\
& $(0.0016)$ & $(0.0019)$ & $(0.0036)$ \\
Reform, RD & 0.0037 & 0.0008 & 0.0043 \\
& $(0.0022)$ & $(0.0025)$ & $(0.0043)$
\end{tabular}

Mean dep var

0.2653

0.2721

0.2301

Reform, DiD

$-0.0013$

Respiratory Diseases
0.0004

(0.0012)

(0.0015)

$-0.0021$

$-0.0003$

0.0019

(0.0029)

Reform, RD

(0.0017)

(0.0020)

$-0.0023$

(0.0035)

\footnotetext{
Mean dep var

0.1425

0.1446

0.1388

Notes: Each number represents an impact from a separate regression by method and demographic group. DiD specification includes a full set of dummy variables for year of birth and municipality of birth as well as separate linear trends for municipalities of birth. RD specification includes separate quadratic polynomials in the running variable before and after the break point, a dummy variable for gender as well as a full set of dummy variables for month of birth. The samples of low and high SES background men and women do not add up to the aggregate sample size because of missing information on father's education in the registry data. Standard errors are in parentheses and are clustered by municipality of birth. Standard errors clustered on the municipality of birth level in parentheses.
} 
Finally, in Appendix Table A7 and Figure A4 we show that the reform did not affect the use of prescription drugs either. Among the many results we show, there are two which are significant at the 5\% level: the use of anti-depressants among high SES individuals declines. However, one must note that we are testing many hypotheses and any adjustment for multiple hypotheses testing would imply $p$-values higher than 5 percent. So these results need to be discounted.

\section{Discussion}

What is the effect of the compulsory schooling reform on mortality? The point estimate implies a very small effect on mortality as we saw earlier. To translate the mortality estimates to implied effects on life expectancy (within the age support of the sample) we first compute the survival functions, based on the estimated hazard rates. Life expectancy is then given by the area under these functions. We see from Table 7 that the point estimates for the reform caused a change in life expectancy of between -0.026 to 0.052 of a month. This is consistent with the effects on hospitalization, repeated here for completeness, which indicate a very small increase. Of course, there is a standard error around these estimates and the extreme of the confidence interval allows for a reduction of mortality as a result of the reform of 1.4 months; similarly, the edge of the CI for hospitalization allows for a reduction of 0.7 days.

TABLE 7- IMPACTS ON LIFE EXPECTANCY AND HOSPITALIZATION.

\begin{tabular}{|c|c|c|c|c|}
\hline \multirow[b]{2}{*}{ Impact of the Reform } & \multicolumn{2}{|c|}{ Life Expectancy (months) } & \multicolumn{2}{|c|}{ Hospitalization (days) } \\
\hline & Point Estimate & $\begin{array}{l}\text { Upper } \\
\text { end of } 95 \% \\
\text { CI }\end{array}$ & $\begin{array}{c}\text { Point } \\
\text { Estimate }\end{array}$ & $\begin{array}{l}\text { Lower end of } \\
95 \% \text { CI }\end{array}$ \\
\hline Difference in Differences & -0.026 & 1.054 & 0.209 & -0.401 \\
\hline Regression Discontinuity & 0.052 & 1.447 & 0.011 & -0.719 \\
\hline \multicolumn{5}{|c|}{ Note: Estimates obtained based on results shown in Tables 4 and 6 , respectively. } \\
\hline \multicolumn{5}{|c|}{$\begin{array}{l}\text { One way to compare our estimates to the overall associations between years of schooling } \\
\text { and mortality would be to derive the implied effect of a year of schooling by using } \\
\text { instrumental variables. However, a priori this is not supported by the nature of the reform that } \\
\text { may have changed not only the quantity of schooling but also its quality. Lower } \\
\text { socioeconomic status individuals (who are the main target) would now attend comprehensive }\end{array}$} \\
\hline
\end{tabular}


monetary support for attending extended schooling. One can argue that many of these mechanisms are beneficial to outcomes, although this may not have been so for higher SES students since their peer group may have been diluted. In any case, it is not valid to use the reform as an excluded IV. If we do, we reject OLS strongly. ${ }^{23}$ The $p$-values of this test are 0.036 and 0.006 based on DiD and RD respectively. For hospitalization the $p$-values are 0.001 and 0.029 respectively. ${ }^{24}$

\section{Conclusions}

In this paper we study the relation between education and health using rich administrative data. We use the introduction of Sweden's comprehensive school, which increased the amount of compulsory schooling, as a source of exogenous variation in educational attainment. We look at overall mortality and mortality by cause of death as outcome measures and consider the population of all Swedes born between 1940 and 1957 who survived until age 16. The follow up period stops in December 2015, allowing us to observe the oldest individuals until age 75 and the youngest until age 58 .

We find no significant effects of the reform on overall mortality, regardless of whether we use difference-in-differences models or a regression discontinuity approach. Indeed, our results indicate that the effect of the reform on mortality is zero for the age window we consider with an upper limit of the 95 percent CI suggesting an increase of life expectancy of at most 1.4 months.

The significance of the findings of no effect of the reform on health lies in the fact that we look at a very large set of outcomes, that the sample is very large, that the effect of the reform on extra schooling is substantial, and that we are able to use two alternative quasiexperimental evaluation methods that yield similar results (DiD and RD). Furthermore, there is established evidence in the literature that the reform significantly increased earnings for the low SES children (Meghir and Palme, 2005). Overall, the results presented here echo others and particularly those of Clarke and Royer (2013) for the UK and Behrman et al. (2011) for Denmark, but contrast with those of Lleras-Muney (2005) for the US and van Kippersluis, O'Donnell, and van Doorslaer (2011) for the Netherlands, who do find relatively large impacts of education on mortality.

\footnotetext{
23 We use the linear probability model specification where we use reform assignment as instrumental variable for years of schooling. $F$ statistics in first stage: 158.5 (DiD) and 157.5 (RD).

${ }^{24}$ Point estimates from the IV models are reported in Table A8 in the Appendix.
} 
The education reform under study in this paper did not only affect quantity of schooling. The centralized and more academic curriculum could potentially have had an effect on ability to critically process information on health related behavior and risks (see e.g. Cutler and Lleras-Muney, 2006, for a discussion). Moreover, the abolition of tracking after $6^{\text {th }}$ grade could have affected health related behaviors through peer-group influences. To distinguish these effects from those of the quantity of schooling is not possible given our data and is our main motivation for not using reform assignment as an instrumental variable for years of schooling.

For the cohorts we are considering in this study, Sweden had an advanced public healthcare system providing services independently of individual income. This may limit the role of one channel through which improved education may affect health, namely that of financial resources. However, the role of education in allowing better access to and understanding of information and in changing one's behavior vis-à-vis investments in one's health is still potentially present. And even in the context of a public healthcare system individual resources may be helpful in improving outcomes. Thus, it is important that our study does not identify an effect of improved education at the lower end of the education distribution on mortality, a result that is very robust. Ultimately, it is important to understand the roles of various channels in improving health, such as resources, access to free healthcare, information and investments in health. 


\section{APPENDIX}

TABLE A1 - ICD 9 AND ICD10 CODES GROUPS USED TO ESTABLISH DIFFERENT CAUSES OF DEATH AND HOSPITALIZATION.

\begin{tabular}{lll}
\hline Cause & ICD9 & ICD10 \\
\hline Treatable causes of death & & \\
Tuberculosis & $010-018,137$ & A15-A19. B90 \\
Malignant neoplasm of cervix uteri & 180 & C53 \\
Chronic rheumatic heart disease & $393-398$ & I05-I09 \\
All respiratory diseases & $460-519$ & J00-J99 \\
Asthma & 493 & J45, J46 \\
Appendicitis & $540-543$ & K35-K38 \\
Abdominal hernia & $550-553$ & K40-K46 \\
Hypertensive and cerebrovascular disease & $401-405,430-438$ & I10-I15, I60-I69 \\
Chollelthiasis and cholecystitis & $574,575.0,575.1$ & K80-K81 \\
Preventable causes of death & & \\
Lung cancer & 162 & C33-C34 \\
Cirrhosis of liver & $571.0-571.3, \quad 571.5-$ & K70, \\
& 571.6 & K74.6 \\
External causes of death & $800-999$ & V, W, X, Y \\
\hline
\end{tabular}




\section{TABLE A2 - THE EFFECTS OF REFORM ASSIGNMENT ON EDUCATIONAL ATTAINMENT}

Panel A Difference-in-Differences estimates of the effect of reform assignment on educational attainment.

\begin{tabular}{|c|c|c|c|}
\hline & (1) & (2) & (3) \\
\hline Change in percent attending: & All & Low SES & High SES \\
\hline \multicolumn{4}{|l|}{ Males and Females } \\
\hline \multirow[t]{2}{*}{ At least comprehensive/junior secondary } & 9.16 & 11.36 & 2.76 \\
\hline & $(0.44)$ & $(5.12)$ & $(0.20)$ \\
\hline \multirow[t]{2}{*}{ More than comprehensive/junior secondary } & 1.58 & 1.73 & 0.60 \\
\hline & $(0.23)$ & $(2.67)$ & $(0.26)$ \\
\hline \multirow[t]{2}{*}{ Changes in years of schooling } & 0.255 & 0.304 & 0.086 \\
\hline & $(0.015)$ & $(0.017)$ & $(0.024)$ \\
\hline Sample size & $1,508,620$ & $1,030,782$ & 287,110 \\
\hline \multicolumn{4}{|l|}{ Males } \\
\hline \multirow[t]{2}{*}{ At least Comprehensive/junior secondary } & 11.28 & 14.12 & 3.12 \\
\hline & $(0.52)$ & $(0.60)$ & $(0.27)$ \\
\hline \multirow[t]{2}{*}{ More than comprehensive/junior secondary } & 2.17 & 2.44 & 0.78 \\
\hline & $(0.29)$ & $(0.34)$ & $(0.36)$ \\
\hline \multirow[t]{2}{*}{ Changes in years of schooling } & 0.301 & 0.363 & 0.097 \\
\hline & $(0.018)$ & $(0.021)$ & $(0.031)$ \\
\hline Sample size & 781,123 & 533,922 & 148,138 \\
\hline \multicolumn{4}{|l|}{ Females } \\
\hline \multirow[t]{2}{*}{ At least Comprehensive/junior secondary } & 6.91 & 8.38 & 2.34 \\
\hline & $(0.41)$ & $(0.48)$ & $(0.21)$ \\
\hline \multirow[t]{2}{*}{ More than comprehensive/junior secondary } & 0.95 & 0.95 & 0.41 \\
\hline & $(0.28)$ & $(0.34)$ & $(0.35)$ \\
\hline \multirow[t]{2}{*}{ Changes in years of schooling } & 0.205 & 0.238 & 0.086 \\
\hline & $(0.021)$ & $(0.024)$ & $(0.035)$ \\
\hline Sample size & 727,497 & 496,860 & 138,972 \\
\hline
\end{tabular}




(1) (2) (3)

Change in percent attending:

All

Low SES

High SES

\section{Males and Females}

At least comprehensive/junior secondary

9.03

11.09

2.44

(0.46)

(5.31)

(0.21)

More than comprehensive/junior secondary

1.57

1.84

0.59

$(0.21)$

(0.40)

(0.38)

Changes in years of schooling

0.241

0.300

0.068

(0.029)

(0.028)

(0.037)

Sample size

$1,508,620$

$1,030,782$

287,110

\section{Males}

At least Comprehensive/junior secondary

11.08

13.70

2.86

(0.67)

(0.29)

More than comprehensive/junior secondary

2.03

2.48

0.70

(0.44)

(0.52)

(0.49)

Changes in years of schooling

0.313

0.375

0.081

(0.023)

(0.033)

(0.050)

Sample size

781,123

533,922

148,138

\section{Females}

At least Comprehensive/junior secondary

6.83

8.29

1.99

(0.41)

(0.49)

(0.29)

More than comprehensive/junior secondary

1.06

1.14

0.48

(0.41)

$(0.48)$

(0.53)

Changes in years of schooling

0.177

0.217

0.055

(0.031)

(0.032)

(0.047)

Sample size

727,497

496,860

138,972

Notes: Each number represents an impact from a separate regression by method and demographic group. DiD specification includes a full set of dummy variables for year of birth and municipality of birth as well as separate linear trends for municipalities of birth. RD specification includes separate quadratic polynomials in the running variable before and after the break point, a dummy variable for gender as well as a full set of dummy variables for month of birth. The samples of low and high SES background men and women do not add up to the aggregate sample size because of missing information on father's education in the registry data. Standard errors are in parentheses and are clustered by municipality of birth. 
TABLE A3 - THE ASSOCIATION BETWEEN YEARS OF SCHOOLING AND HOSPITALIZATION.

\begin{tabular}{lcccc}
\hline & $\begin{array}{c}\text { Days in } \\
\text { hospital care }\end{array}$ & Cancer & $\begin{array}{c}\text { Circulatory } \\
\text { diseases }\end{array}$ & $\begin{array}{c}\text { Respiratory } \\
\text { diseases }\end{array}$ \\
\hline Years of schooling & -1.947 & 0.0026 & -0.0042 & -0.0017 \\
& $(0.035)$ & $(0.0001)$ & $(0.0001)$ & $(0.0001)$ \\
Mean dep variable & 27.10 & 0.1104 & 0.2653 & 0.1425 \\
$N$ & $1,305,121$ & $1,305,121$ & $1,305,121$ & $1,305,121$
\end{tabular}

Note: Indicator variables for gender as well as year of birth also included in the specification. All dead before 2015 excluded from the sample.

TABLE A4 - THE ASSOCIATION BETWEEN YEARS OF SCHOOLING AND CONSUMPTION OF PRESCRIBED DRUGS.

\begin{tabular}{lcccc}
\hline & All & $\begin{array}{c}\text { Musculo- } \\
\text { skeletal } \\
\text { System }(M)\end{array}$ & $\begin{array}{c}\text { Respiratory } \\
\text { System }(R)\end{array}$ & $\begin{array}{c}\text { Nervous } \\
\text { System }(N)\end{array}$ \\
\hline Have experiences of & 0.0001 & -0.0003 & 0.0001 & -0.0033 \\
Mean of dependent variable & $(0.0001)$ & $(0.00003)$ & $(0.00005)$ & $(0.0002)$ \\
Defined daily doses & 0.9414 & 0.0211 & 0.0368 & 0.628 \\
Mean of dependent variable & & & -11.50 & -45.44 \\
\hline Neuroleptics & -313.07 & -6.02 & $(0.55)$ & $(1.16)$ \\
& $(4.57)$ & $(0.24)$ & 528.17 & $1,122.56$ \\
\hline Have experiences of & $8,405.01$ & 285.59 & Antidepressa & \\
Mean of dependent variable & $(N 2)$ & $c s(N 5)$ & $n t s(N 6)$ & -0.0033 \\
& -0.0059 & -0.0015 & $(0.0001)$ & \\
Defined daily doses & $(0.0002)$ & $(0.0002)$ & 0.217 & \\
Mean of dependent variable & 0.516 & 0.327 & & \\
\hline
\end{tabular}

Notes: Each number represents an impact from a separate regression by method and demographic group. DiD specification includes a full set of dummy variables for year of birth and municipality of birth as well as separate linear trends for municipalities of birth. RD specification includes separate quadratic polynomials in the running variable before and after the break point, a dummy variable for gender as well as a full set of dummy variables for month of birth. The samples of low and high SES background men and women do not add up to the aggregate sample size because of missing information on father's education in the registry data. Standard errors are in parentheses and are clustered by municipality of birth. 
TABLE A5 - REFORM EFFECT ON MORTALITY BY AGE OF DEATH. UPPER PANEL: LINEAR PROBABILITY MODEL ESTIMATES FOR DEATHS IN DIFFERENT AGE INTERVALS. LOWER PANEL: COX PROPORTIONAL HAZARD MODEL ESTIMATES WHEN SAMPLE HAS BEEN RESTRICTED TO UPPER AGE LIMITS.

\begin{tabular}{|c|c|c|c|c|c|c|c|}
\hline Age interval & & $40-44$ & $45-49$ & $50-54$ & 55-59 & $60-64$ & $65-70$ \\
\hline \multirow[t]{4}{*}{ DiD, LPM } & & 0.000 & 0.000 & 0.000 & 0.000 & - & 0.001 \\
\hline & & 2 & 1 & 6 & 3 & 0.0019 & 1 \\
\hline & & $(0.000$ & $(0.00$ & $(0.00$ & $(0.00$ & $(0.001$ & $(0.00$ \\
\hline & & 3) & 04) & 06) & 08) & 4) & 26) \\
\hline \multirow[t]{4}{*}{ RD, LPM } & & 0.000 & - & - & 0.001 & - & - \\
\hline & & 1 & 0.0001 & 0.0003 & 1 & 0.0027 & 0.0052 \\
\hline & & $(0.000$ & $(0.00$ & $(0.00$ & $(0.00$ & $(0.002$ & $(0.00$ \\
\hline & & 4) & 06) & 08) & 11) & 1) & 40) \\
\hline N (Thousands) & & 1,573 & 1,567 & 1,551 & 1,371 & 1,025 & 570 \\
\hline Age interval & -40 & -45 & -50 & -55 & -60 & -65 & -70 \\
\hline DiD, $\quad$ stratified & 0.980 & 1.000 & 0.991 & 1.007 & 1.009 & 0.995 & 0.998 \\
\hline \multirow[t]{3}{*}{ Cox } & 2 & 6 & 8 & 4 & 6 & 5 & 7 \\
\hline & $(0.024$ & $(0.021$ & $(0.01$ & $(0.01$ & $(0.01$ & $(0.010$ & $(0.01$ \\
\hline & 3) & 7) & 81) & $50)$ & 22) & 8) & 03) \\
\hline $\mathrm{RD}$, & 0.972 & 0.996 & 0.972 & 0.992 & 1.009 & 0.992 & 0.996 \\
\hline \multirow[t]{3}{*}{ Regression } & 7 & 5 & 8 & 1 & 6 & 8 & 7 \\
\hline & $(0.032$ & $(0.027$ & $(0.02$ & $(0.01$ & $(0.01$ & $(0.014$ & $(0.01$ \\
\hline & 1) & 8) & 25) & $85)$ & 58) & 7) & 44) \\
\hline
\end{tabular}

Notes: Each number represents an impact from a separate regression by method and demographic group. Standard errors are in parentheses and are clustered by municipality of birth. DiD LPM specification includes a full set of dummy variables for year of birth and municipality of birth as well as separate linear trends for municipalities of birth. Stratified Cox regressions include year of first implementation specific linear trends. RD specification includes separate quadratic polynomials in the running variable before and after the break point, a dummy variable for gender as well as a full set of dummy variables for month of birth.. The samples of low and high SES background men and women do not add up to the aggregate sample size because of missing information on father's education in the registry data. Standard errors are in parentheses and are clustered by municipality of birth. 
TABLE A6 - THE EFFECTS OF EDUCATION REFORM ON MORTALITY BY CAUSE OF DEATH. COX PROPORTIONAL HAZARD REGRESSIONS. MEN AND WOMEN.

(1)

All

\begin{tabular}{lccc} 
& All & Low SES & High SES \\
\hline & & & \\
Reform, stratified & 0.9639 & Preventable & 0.9159 \\
& $(0.0359)$ & $(0.0450)$ & $(0.0942)$ \\
Reform, RD & 0.9212 & 0.9586 & 0.8867 \\
& $(0.0434)$ & $(0.0545)$ & $(0.1099)$ \\
& & & \\
Deaths & 26,043 & 17,332 & 3,217 \\
\hline \multirow{2}{*}{ Reform, stratified } & 1.0488 & Treatable & 1.0454 \\
Reform, RD & $(0.0369)$ & $1.0891 *$ & $(0.0937)$ \\
& 1.0621 & $(0.0516)$ & 1.1185 \\
Deaths & $(0.0525)$ & 1.0861 & $(0.1183)$ \\
$\mathrm{N}$ & & $(0.0680)$ & 3,937 \\
\hline
\end{tabular}

Notes: Each number represents an impact from a separate regression by method and demographic group. DiD specification includes a full set of dummy variables for year of birth and municipality of birth as well as separate linear trends for municipalities of birth. RD specification includes separate quadratic polynomials in the running variable before and after the break point, a dummy variable for gender as well as a full set of dummy variables for month of birth. The samples of low and high SES background men and women do not add up to the aggregate sample size because of missing information on father's education in the registry data. Standard errors are in parentheses and are clustered by municipality of birth. 
TABLE A7 - THE EFFECTS OF EDUCATION REFORM ON PRESCRIBED DRUG CONSUMPTION IN DAILY DOSES. MEN AND WOMEN.

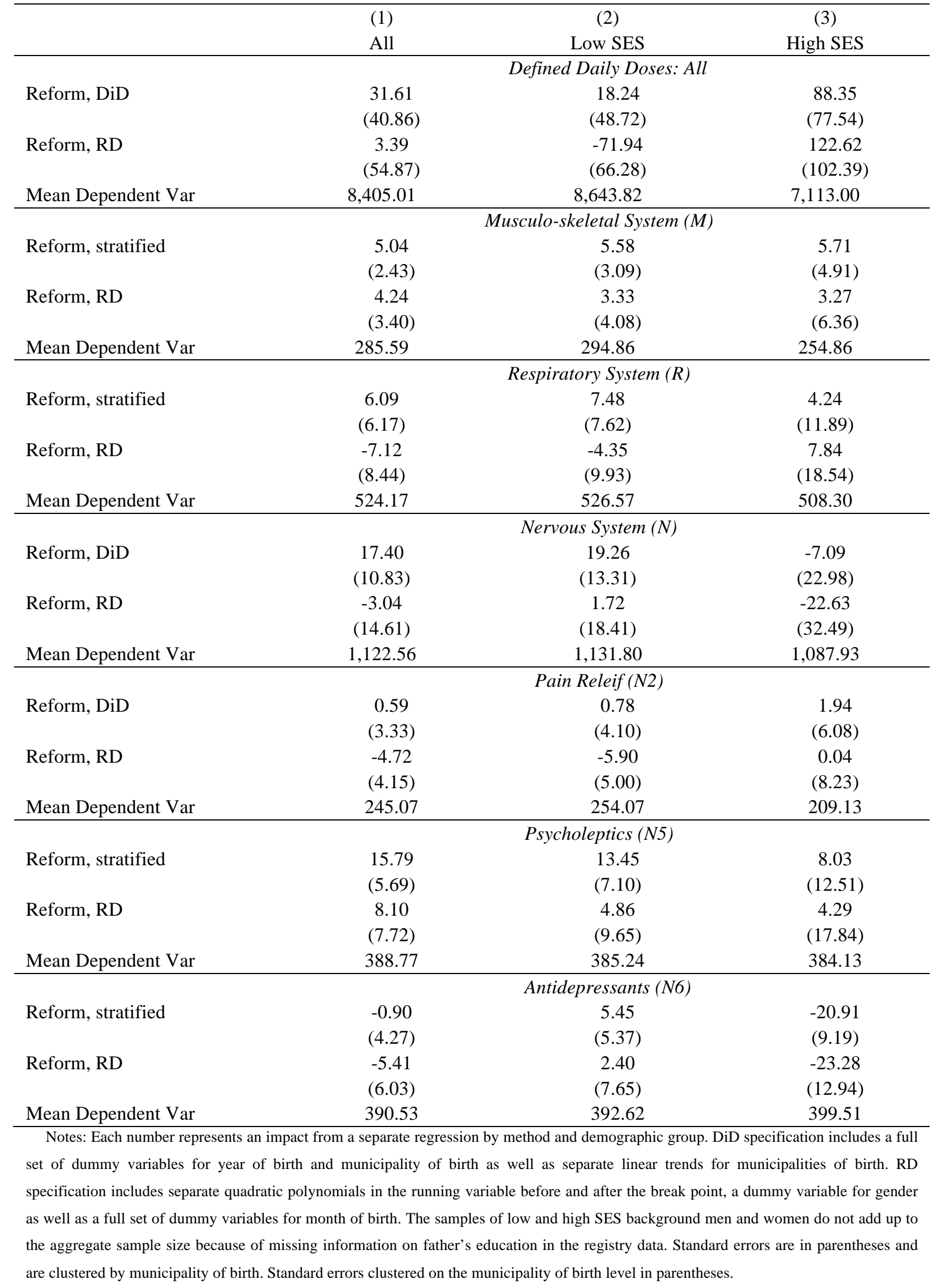


TABLE A8 - IV ESTIMATES OF THE REFORM EFFECT ON MORTALITY AND HOSPITALIZATION.

\begin{tabular}{lcc}
\hline & Mortality & Hospitalization \\
\hline Years of schooling, DiD IV & 0.0019 & 6.879 \\
Years of schooling, RD IV & $(0.0086)$ & $(303.889)$ \\
& 0.0054 & 3.746 \\
Sample size & $(0.0089)$ & $(2.598)$ \\
\hline
\end{tabular}

Note: DiD specification includes a full set of dummy variables for year of birth and municipality of birth as well as separate linear trends for municipalities of birth. RD specification includes separate quadratic polynomials in the running variable before and after the break point, a dummy variable for gender as well as a full set of dummy variables for month of birth. 
Panel A
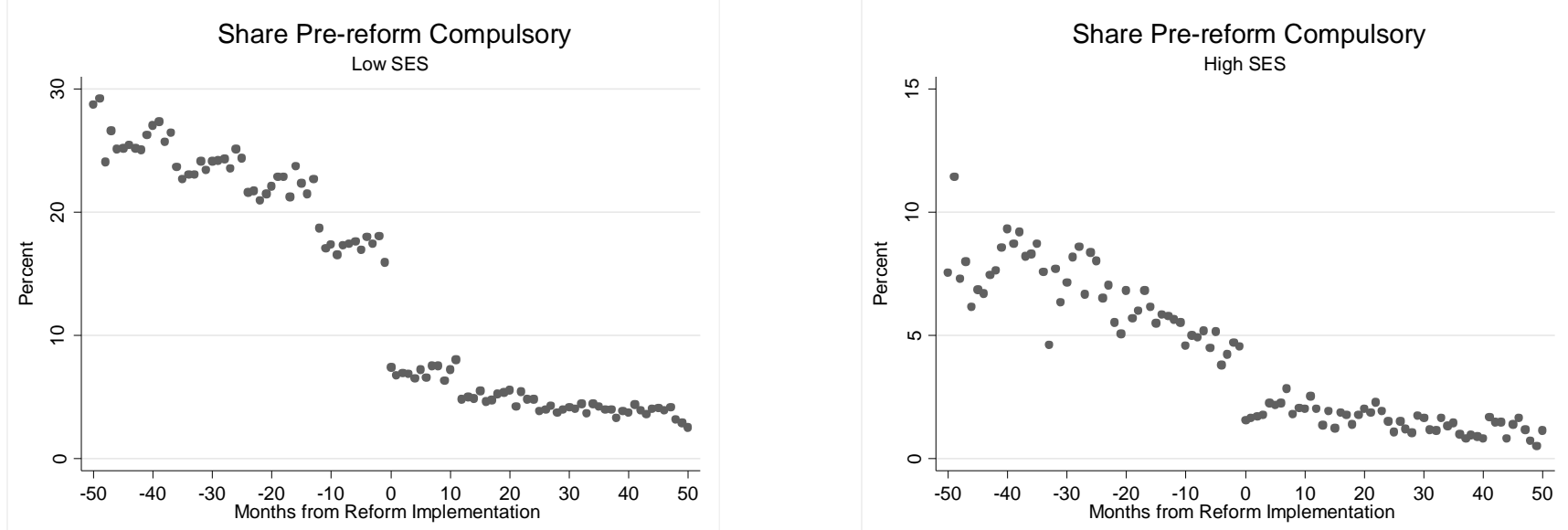

Panel B
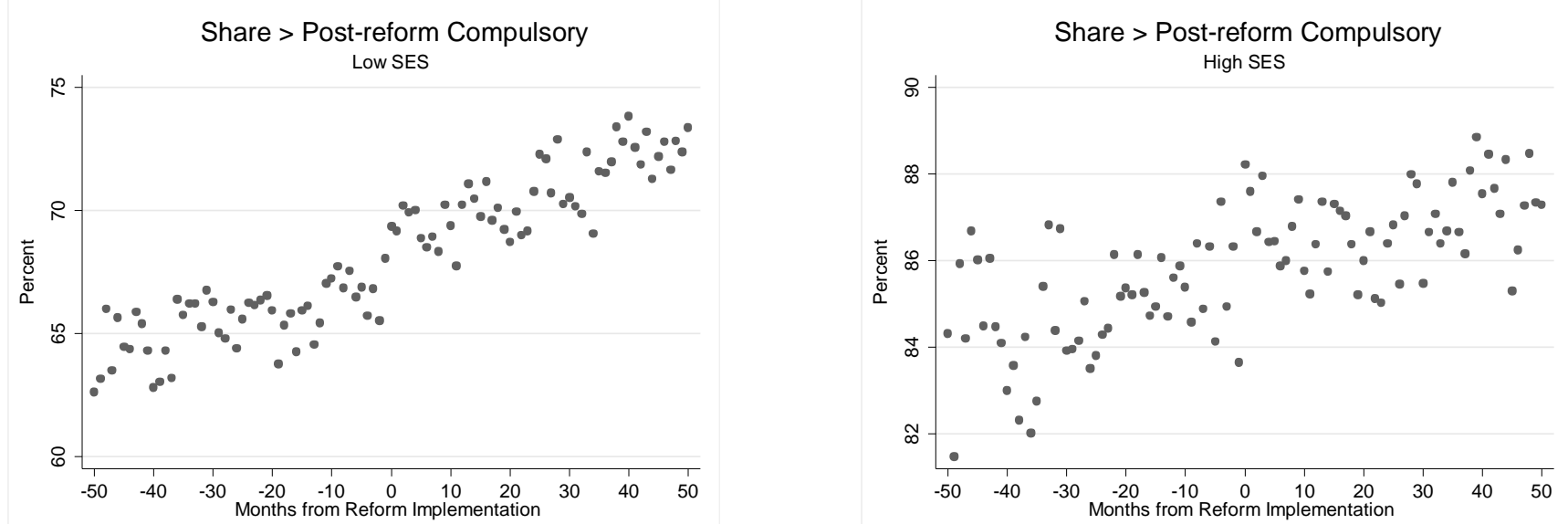

Panel C
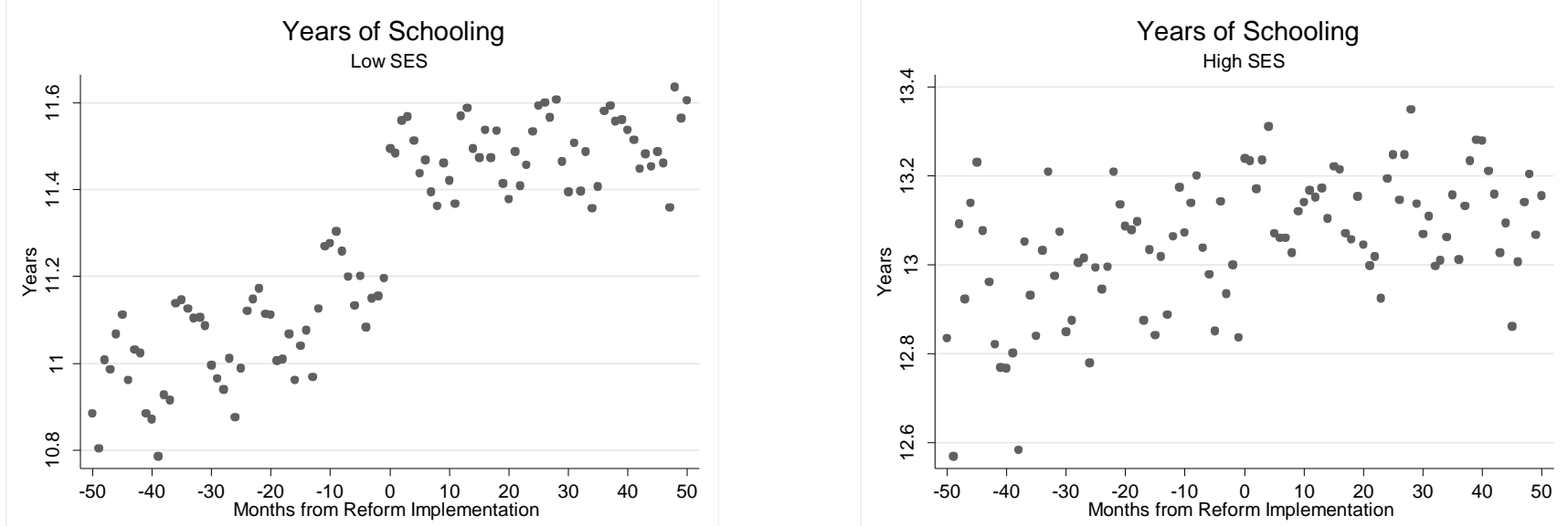

FIGURE A1. EFFECTS OF THE REFORM ON EDUCATIONAL ATTAINMENTS BY FATHER'S EDUCATION. THE HORIZONTAL AXIS MEASURES THE NUMBER OF MONTHS BETWEEN THE MONTH OF BIRTH FOR THE INDIVIDUALS INCLUDED IN THE CELL AND THE MONTH OF BIRTH OF THE FIRST COHORT OF INDIVIDUALS AFFECTED BY THE REFORM (A) SHARE WITH LESS FINAL EDUCATION THAN THE PRE- 
REFORM COMPULSORY LEVEL; (B) EFFECT ON EDUCATIONAL ATTAINMENT BEYOND THE POSTREFORM COMPULSORY LEVEL; (C) YEARS OF SCHOOLING.
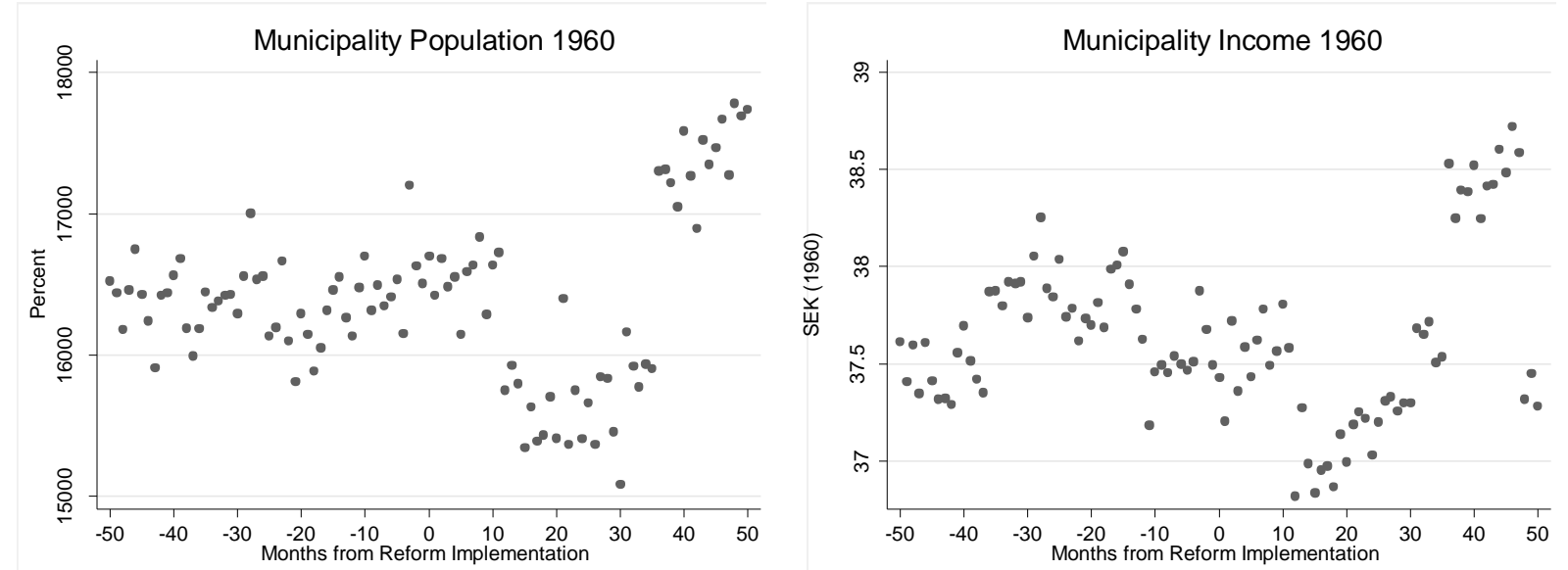

FIGURE A2. OUTCOMES FOR POTENTIAL CONFOUNDERS. RIGHT PANEL: MUNICIPALITY AVERAGE INCOME IN 1960; LEFT PANEL: MUNICIPALITY POPULATION SIZE. THE HORIZONTAL AXIS MEASURES THE NUMBER OF MONTHS BETWEEN THE MONTH OF BIRTH FOR THE INDIVIDUALS INCLUDED IN THE CELL AND THE MONTH OF BIRTH OF THE FIRST COHORT OF INDIVIDUALS AFFECTED 

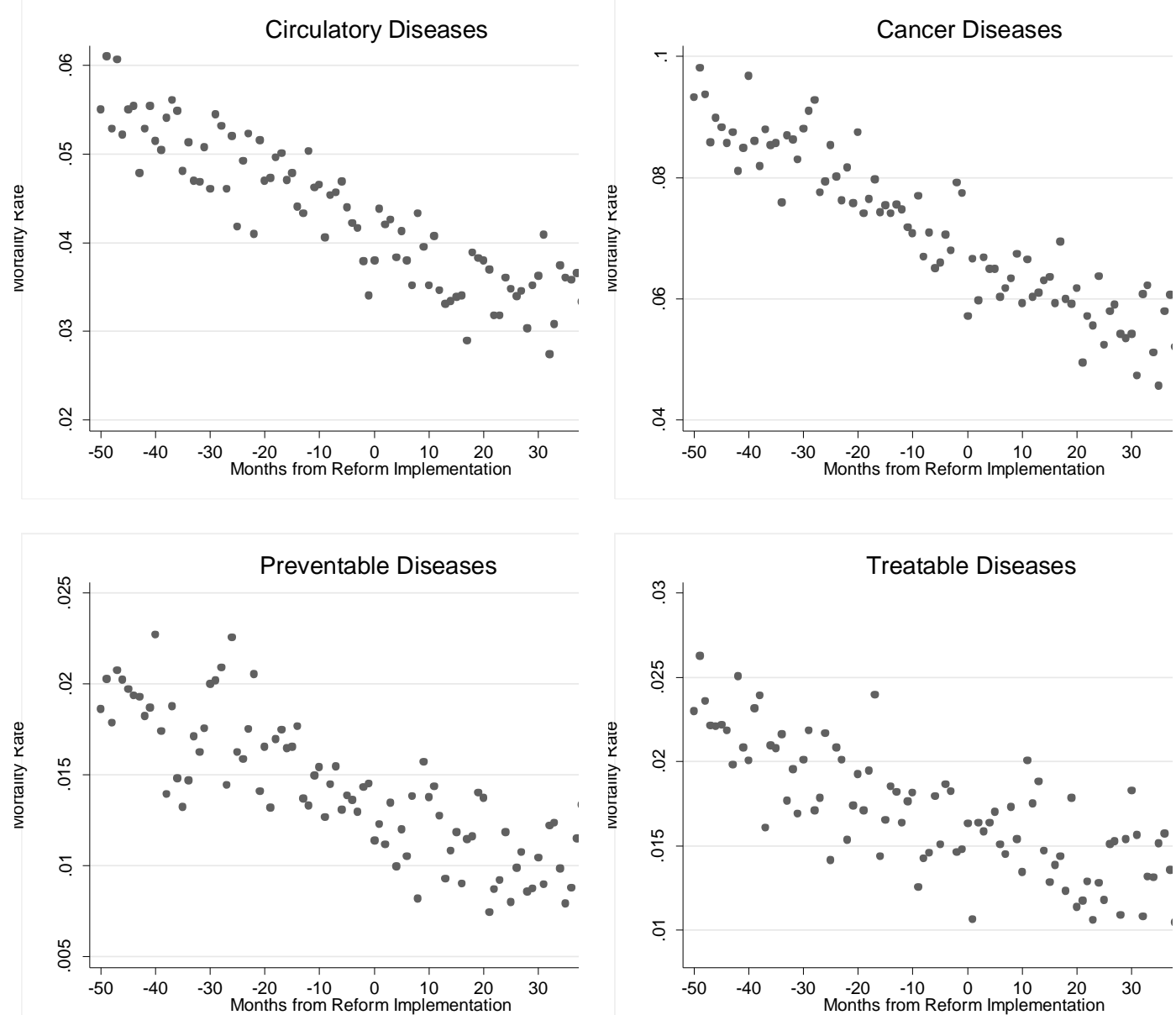

Figure A3. REFORM EFFECT ON MORTALITY By CAUSE OF DEATH. THE HORIZONTAL AXIS MEASURES THE NUMBER OF MONTHS BETWEEN THE MONTH OF BIRTH FOR THE INDIVIDUALS INCLUDED IN THE CELL AND THE MONTH OF BIRTH OF THE FIRST COHORT OF INDIVIDUALS AFFECTED BY THE REFORM. 

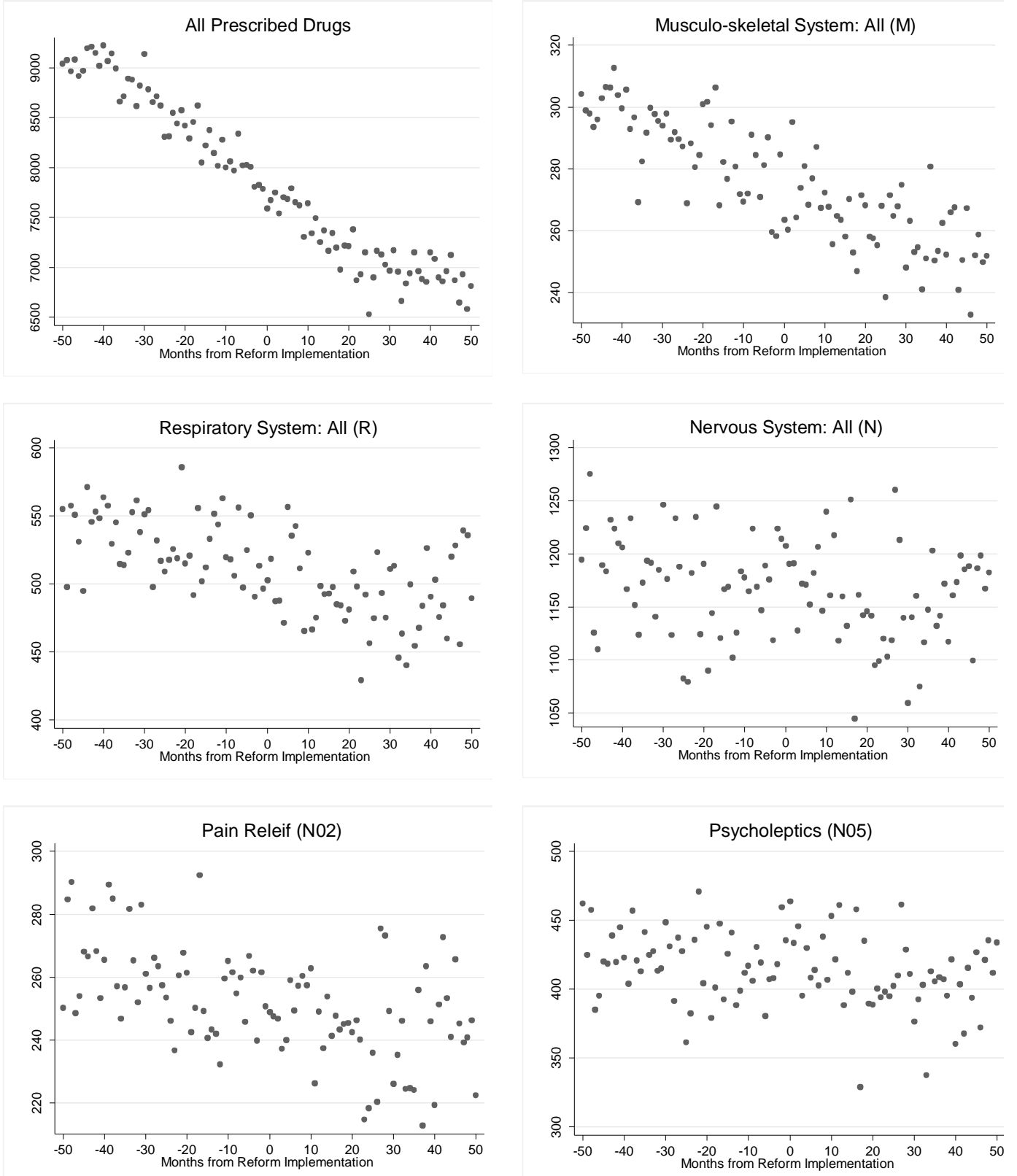


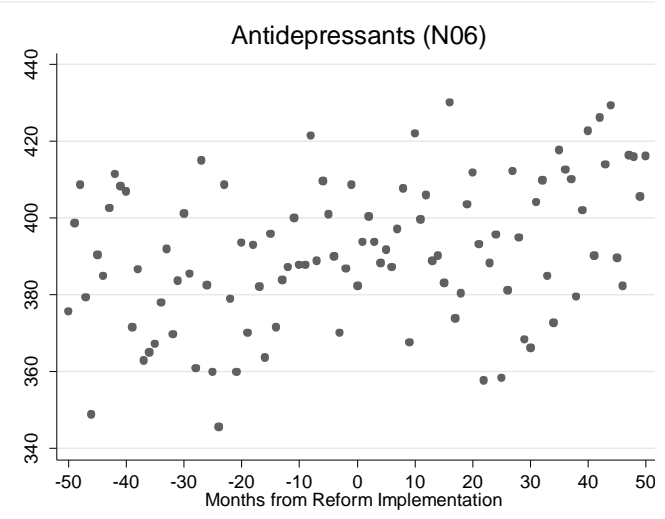

FIgURE A4. THE EFFECTS OF EDUCATION REFORM ON PRESCRIBED DRUG CONSUMPTION IN DAILY DOSES BY ATC MAIN CATEGORY. THE HORIZONTAL AXIS MEASURES THE NUMBER OF MONTHS BETWEEN THE MONTH OF BIRTH FOR THE INDIVIDUALS INCLUDED IN THE CELL AND THE MONTH OF BIRTH OF THE FIRST COHORT OF INDIVIDUALS AFFECTED BY THE REFORM. MEN AND WOMEN.

\section{REFERENCES}

Altonji, Joseph and Rebecca Blank 1999. "Race and Gender in the Labor Market." In Handbook of Labor Economics, Volume 3, ed. Orley Ashenfelter and David Card, 3143-3259. Amsterdam: North-Holland, Elsevier Science.

Athey, Susan and Guido Imbens 2006. "Identification and inference in nonlinear difference-in-differences models." Econometrica, 74(2): 431-497.

Behrman, Jere R., et al. 2011. "Does More Schooling Reduce Hospitalization and Delay Mortality? New Evidence Based on Danish Twins.” Demography, 48(4): 1347-1375.

Blundell, Richard W., Monica Costa-Dias, Costas Meghir and John van Reenen 2004. "Impact of a Mandatory Job Search Program." Journal of the European Economic Association, 2(4): 569-606. 
Clark, Damon and Heather Royer 2013. "The effect of education on adult mortality and health: Evidence from Britain" The American Economic Review, 103(6): 2087-2120.

Cleves, Mario A., William. W. Gould and Roberto G. Gutierrez 2004. An Introduction to Survival Analysis Using STATA, STATA Press: Texas, USA.

Cox, David R., and David Oakes 1984. Survival Analysis. London: Chapman and Hall.

Dobkin, Carlos and Fernando Ferreira 2010. "Do school entry laws affect educational attainment and labor market outcomes?" Economics of Education Review, 29(1): 40-54.

Cutler, David and Adriana Lleras-Muney 2006. "Education and health: evaluating theories and evidence. In (eds.) J.S. House, R.F. Schoeni, G.A. Kaplan, and H. Pollack, The Health Effects of Social and Economic Policy, New York: Russell Sage Foundation.

Gelman, Andrew and Guido Imbens 2014. "Why high-order polynomials should not be used in regression discontinuity designs." Working paper w20405. National Bureau of Economic Research.

Grossman, Michel 2006. "Education and Nonmarket Outcomes." In Handbook of the Economics of Education, ed. Eric Hanushek and Finis Welch, 577-633. Amsterdam: North-Holland, Elsevier Science.

Holmlund, Helena 2007. "A Researcher's Guide to the Swedish Compulsory School Reform.” Working paper 9/2007, Swedish Institute for Social Research, Stockholm University.

Honoré, Bo E. and Adriana Lleras-Muney 2006. "Bounds in competing risks models and the war on cancer." Econometrica, 74(6): 1675-1698.

Lager, Anton and Jenny Torssander 2012. "Causal effect of education on mortality in a quasi-experiment on 1.2 million Swedes." Proceedings of the National Academy of Sciences, 109 (22): 8461-8466. 
Lleras-Muney, Adriana 2005. “The Relationship Between Education and Adult Mortality in the United States.” Review of Economic Studies, 72: 189-221.

Marklund, Sixten 1981. Skolsverige 1950-1975: Försöksverksamheten. Stockholm: Liber Utbildningsförlaget.

McCrary, Justin 2008. "Manipulation of the running variable in the regression discontinuity design: A density test." Journal of Econometrics, 142(2): 698714.

Mazumder, Bhashkar 2008. "Does Education Improve Health: A Reexamination of the Evidence from Compulsory Schooling Laws." Economic Perspectives, 33(2): 2-16.

Mazumder, Bhashkar .2012. "The Effects of Education on Health and Mortality." Nordic Economic Policy Review, 1/2012: 261-301.

Meghir, Costas and Mårten Palme 2005. "Educational Reform, Ability, and Family Background.” American Economic Review, 95(1): 414-424.

Meghir, Costas Mårten Palme and Emilia Simeonova 2012. "Education, Health and Mortality: Evidence from a Social Experiment." Working Paper w17932, National Bureau of Economic Research.

Oreopoulos, Philip 2006. "Estimating Average and Local Average Treatment Effects of Education when Compulsory School Laws Really Matter." American Economic Review, 96(1): 152-175.

Socialstyrelsen 2009a. The Swedish Cause of Death Registry. Sweden, Stockholm. 2009.

Socialstyrelsen 2009b. The Swedish National Patient Register. Inpatient diseases in Sweden 1987-2007. Sweden, Stockholm. 2009.

Spasojevic, Jasmina 2010. "Effects of Education on Adult Health in Sweden: Results from a Natural Experiment." In Current Issues in Health Economics (Contributions to Economic Analysis, Volume 290), ed. Daniel Slottje and Rusty Tchernis, 179-199. Emerald Group Publishing Limited. 
Statistics Sweden 2011. Integrated database for labour market research. Labour and Education Statistics 2011:4.

Statistics Sweden 2012. Flergenerationsregistret Örebro: Statistics Sweden.

van Kippersluis, Hans, Owen O’Donnell and Eddy van Doorslaer 2011. 'Long-

Run Returns to Education: Does Schooling Lead to an Extended Old Age?" Journal of Human Resources 46(4): 695-721. 